
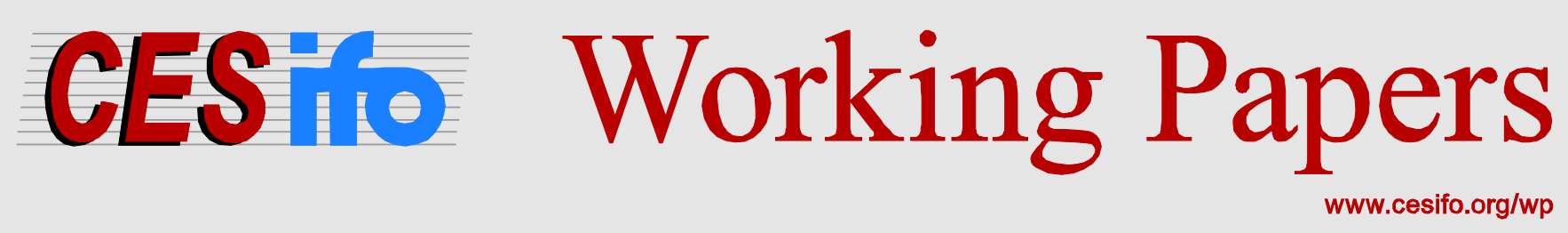

\title{
Taxing Banks: An Evaluation of the German Bank Levy
}

\author{
Claudia M. Buch \\ Björn Hilberg \\ Lena Tonzer
}

\section{CESIFO WORKING PAPER NO. 4704 \\ CATEGORY 7: MONETARY POLICY AND INTERNATIONAL FinANCE \\ MARCH 2014}

Presented at CESifo Area Conference on Macro, Money \& International Finance, February 2014

An electronic version of the paper may be downloaded

- from the SSRN website:

WWW.SSRN.cOm

- from the RePEc website:

- from the CESifo website:

www.RePEc.org

www.CESifo-group.org/wp 


\title{
Taxing Banks: An Evaluation of the German Bank Levy
}

\begin{abstract}
Bank distress can have severe negative consequences for the stability of the financial system, the real economy, and public finances. Regimes for restructuring and restoring banks financed by bank levies and fiscal backstops seek to reduce these costs. Bank levies attempt to internalize systemic risk and increase the costs of leverage. This paper evaluates the effects of the German bank levy implemented in 2011 as part of the German bank restructuring law. Our analysis offers three main insights. First, revenues raised through the bank levy are minimal, because of low tax rates and high thresholds for tax exemptions. Second, the bulk of the payments were contributed by large commercial banks and the head institutes of savings banks and credit unions. Third, the levy had no effect on the volume of loans or interest rates for the average German bank. For the banks affected most by the levy, we find evidence of fewer loans, higher lending rates, and lower deposit rates.
\end{abstract}

JEL-Code: G210, G280, C210.

Keywords: bank levy, bank lending, interest rates, German banks.

\author{
Claudia M. Buch* \\ Halle Institute for Economic Research (IWH) \\ Kleine Maerkerstraße 8 \\ Germany-06108 Halle (Saale) \\ claudia.buch@iwh-halle.de
}

\author{
Björn Hilberg \\ German Federal Bank \\ Wilhelm-Epstein-Straße 14 \\ Germany-60431 Frankfurt am Main \\ bjoern.hilberg@bundesbank.de
}

\author{
Lena Tonzer \\ European University Institute \\ Via della Piazzuola 43 \\ Italy-50133 Florence \\ lena.tonzer@eui.eu
}

*corresponding author

February 2014

This paper was written within the context of the Priority Programme SPP1578, "Financial Market Imperfections and Macroeconomic Performance,” of the German National Science Foundation (DFG). Its development also occurred partly during visits of the authors to the research centre of the Deutsche Bundesbank. The hospitality of the Bundesbank and access to its bank-level data are gratefully acknowledged. The authors also thank Elena Carletti, Tommaso Oliviero, and participants of a $\mathrm{PhD}$ workshop at the Frankfurt School of Finance \& Management for helpful comments. They further thank participants in the seminar series at Deutsche Bundesbank and the CESifo Area Conference on Macro, Money \& International Finance. All errors and inconsistencies are solely our own. 


\section{Motivation}

Bank distress can have severe negative consequences not just for the stability of the financial system but also for the real economy and public finances. Systemic banking crises have imposed fiscal costs of up to $6.8 \%$ of a country's gross domestic product (GDP) and output has fallen by $23 \%$ compared with long-run trends (Laeven and Valencia 2012). Crises increase public debt significantly, aggravating the risk of public sector default (Reinhart and Rogoff 2011, 2013). Furthermore, recessions triggered by debt crises are particularly severe and long-lasting (Taylor 2012).

To lower the probability of banking crises and internalize the costs of bank distress, policy makers have chosen two main instruments. First, the new Basel III regulations impose higher capital requirements for banks (and thus lower leverage), demand better quality of regulatory bank capital, and implement capital buffers to account for systemic risk. Second, regimes for restructuring and restoring banks have been established. They rely on fiscal backstops and bank levies, which seek to both internalize systemic risk and increase the costs of leverage (International Monetary Fund [IMF] 2010; Perotti and Suarez 2011; Shin 2010).

In this paper, we evaluate the effects of the German bank levy implemented in 2011 as part of the German bank restructuring law. We combine several data sets provided by the Deutsche Bundesbank to analyze whether the bank levy affected bank behavior. In particular, we consider responses in terms of lending volume, pricing of new loans, and deposits. By using a difference-in-difference approach, our study exploits two features of the levy design. First, its specific terms were uncertain until the restructuring fund regulation actually passed. Second, the levy was applied in retrospect to banks' balance sheets. Because the levy thus was imposed exogenously, we can distinguish the behavior of banks that paid the tax (treated banks) from those that did not (control group). We focus on differences in the banks' behavior before (2003-2010) versus after (2011) the introduction of the levy, which enables us to isolate the effect of the levy cleanly. However, we cannot assess longer-term adjustments of the banks' business models.

The German bank levy is designed to increase with banks' total liabilities (and thus bank leverage), from which selected positions (e.g., equity, retail deposits) are deducted, as well as the amount of derivative exposures. Banks are exempt from paying the tax if their total contribution-relevant liabilities are less than $€ 300$ million. Tax payments are capped at $20 \%$ of profits; special purpose banks, which do not pay corporate income taxes, are not addressed by this tax. With this financial stability contribution, the government aimed to correct the adverse effects of high leverage. In contrast, a financial transaction tax imposes penalties on certain kinds of financial transactions, and financial activity taxes invoke levies for financial sector profits and remuneration. Of the 14 European countries that have imposed variants of 
these taxes in the past five years, most of them (like Germany) opted for financial stability contributions (Gottlieb et al. 2012). The revenues from these bank levies have been highest in Hungary $(0.7 \%$ of GDP) but only $0.02 \%$ of GDP in Germany. Thus the revenues are consistently well below the $2-3 \%$ estimated costs of banking crises relative to GDP. In addition, the German version differs in two main respects from other European bank levies: First, the German levy applies to foreign branches of German banks but not foreign subsidiaries. In most other countries, foreign affiliates are exempted from the levy. Second, Germany (and France) exempts small banks and development banks from the levy.

In analyzing the effects of the German bank levy, we focus on two main questions. First, what is the tax burden for different types of banks? The bank levy intends to provide incentives for banks to internalize their contributions to systemic risk. Large, and thus presumably systemically more important, banks pay higher levies. The design of the bank levy further implies that banks with riskier business models make higher contributions. Those with a market-based funding strategy and those involved in derivative trading are charged higher levies, whereas banks that adopt traditional business models, such as retail deposits and lending, are charged less. We find that the contributed bank levies correlate strongly with the size of banks. The largest commercial banks and head institutes of savings banks and credit unions account for the bulk of the payments, whereas smaller banks (77\% of the total) do not contribute to the levy at all. Other bank-specific features, such as the structure of assets and liabilities or the profitability of banks, are virtually uncorrelated with the levy.

Second, how does the levy affect bank behavior? In the short run, banks could adjust by reducing their lending activities, increasing their loan rates, and/or lowering deposit rates to compensate for the increase in their funding costs due to the levy. The extent of this adjustment depends on the pricing power in loan markets. We focus on a subsample of banks for which we have information about new loans, the lending rates of these new loans, and the interest rates paid for new deposits. We find no effects of the levy for the banking system as a whole. This seems not surprising given that most banks are not affected by the levy or, if they are, provide only very minor contributions. If we account for the size of the banks' contribution-relevant liabilities though, we find that banks affected by the levy more tend to lower their lending, increase the interest rates charged on new loans, and reduce interest rates paid for new deposits. In the long run, a bank levy might also affect banks' risk-taking behavior. If the levy fails to internalize risk sufficiently, its introduction could induce moral hazard effects, similar to those of deposit insurance systems. However, in the relatively short time since the introduction of the German bank levy, we cannot test for such longer-run adjustments in bank behavior or business models. The comparison of the distribution of taxed balance sheet components before (2010) and after (2011) the introduction of the levy offered no evidence of significant short-run changes in banks' business models. 
Our research contributes to two strands of literature. One stream indicates that banks pass higher taxes on to borrowers. Demirguç-Kunt and Huizinga $(1999,2001)$ use bank-level data for 80 countries, both developing and industrialized markets, to show that higher taxes lead to higher pre-tax profitability of banks. That is, banks pass their corporate income taxes on to customers, though this effect is stronger among local than foreign banks. Albertazzi and Gamabcorta (2010) investigate similar issues using data for 10 industrialized countries during 1981-2003. They also find that corporate income taxes get passed on to borrowers, through increased interest rates and reduced lending. This high pass-through rate is confirmed by Chiorazzo and Milani (2011) with data on European banks over the period 1990-2005. However, their result contrasts with Capelle-Blancard and Havrylchyk's (2013) sample of European banks for 1992-2008, for which they uncover no evidence of significant passthrough. These latter authors are the only ones to account for endogeneity and they focus on implicit taxes on banks. Our findings contribute to this literature by revealing a negative impact of the bank levy on bank loans and a positive impact on loan rates, though only for the banks significantly affected by the levy.

Another strand of literature focuses on regulatory measures designed to internalize banks' contributions to systemic risk. Concrete policy proposals by the IMF (2010), in its report to the G20, describe possible schemes of financial sector taxation. A proposal for liquidity charges is given by Perotti and Suarez (2009). They argue that liquidity charges increasing in the amount of short-term wholesale liabilities and weighted by the maturity mismatch between assets and liabilities might discourage excessive reliance on short-term funding and generate emergency liquidity funds for crisis times. Shin (2010) raises the idea of a tax on banks' non-core liabilities, which might lower their reliance on short-term wholesale funding as a means to finance excessive balance sheet expansions during booms. Recent evidence on the positive relationship between the use of wholesale funding and procyclicality of leverage is provided by Damar et al. (2013) for the Canadian banking sector. Thus and in contrast to capital requirements under Basel II, bank taxes should mitigate procyclicality in the financial sector. Behn et al. (2013), for example, document for the German banking system a reduction in lending to non-financial firms during the recent crisis due to procyclical capital charges under the Basel II internal ratings-based approach. Although the time since the introduction of the German bank levy (2011) is too short to analyze these long-run effects, Schweikhard and Wahrenburg (2013) show that within the German tax scheme banks that contribute more to systemic risk pay higher taxes. Using a sample of 41 large banks, they compare the effectiveness of the French, German, and U.K. bank levies for internalizing systemic risk. Specifically, they compare the levies these banks would have paid in 2007-2010 with their "too-big-to-fail" premium (i.e., the funding cost advantage of being so large) and find that none of the tax schemes fully internalize the negative externality; nevertheless, levies in all tax schemes correlate positively with banks' contributions to systemic risk. Unlike our research, their analysis focuses on a selected sample of large banks and the link between 
systemic risk measures and hypothetical tax payments in different regulatory regimes. Our objective instead is to evaluate the immediate effects of actual levies paid according to the German regulation on the interest rate setting and lending behavior of German banks. We calculate tax payments using confidential balance sheet data from the Deutsche Bundesbank, which are available for both large commercial banks but also smaller savings banks and credit unions.

Theoretically, De Nicolò et al. (2012) use a dynamic model to study the effects of taxation, capital, and liquidity requirements on bank lending, efficiency, and welfare. Their results suggest that corporate income taxes dominate a tax on non-deposit liabilities, because the former generates higher tax revenues but mitigates the negative effects on lending and social welfare compared with a tax on non-deposit liabilities. Perotti and Suarez (2011) compare the effectiveness of Pigovian taxes on short-term funding with the impact of liquidity ratios for reducing systemic externalities. In their model, an optimal allocation results from introducing Pigovian taxes on short-term funding, given that banks differ only in their investment possibilities. This result disappears with the introduction of heterogeneity in banks' risktaking. In this scenario, bank taxes are no longer sufficient to align gambling incentives and excessive credit expansion. If we compare the design of the German bank levy with taxes proposed in theoretical models and policy proposals, it becomes obvious that they all share the idea of targeting the liability side of banks' balance sheet and internalizing systemic risk due to excessive reliance on short-term wholesale funding.

The paper is structured as follows. In the next section, we describe the design and legal background of the German bank levy. In Section 3, we introduce our data and provide some descriptive statistics. Section 4 contains the empirical model and the baseline regression results. We conclude in Section 5.

\section{German Bank Levy: Design and Legal Background}

\subsection{Timing of the Legislation}

The German bank levy was charged for the first time in 2011, as part of the changes to the regulatory framework of the banking system following the financial crisis that began in 2007 . The levy applies to all credit institutions with a banking license, as specified in the German Banking Act (Kreditwesengesetz; KWG). The levy finances the Restructuring Fund (Restrukturierungsfonds), which has a target size of $€ 70$ billion. Thus far though, only $€ 1.28$ billion have been collected from the banks over two years. ${ }^{1}$ These funds are earmarked to rescue banks in distress if their failure would endanger the systemic stability of the banking

\footnotetext{
${ }^{1}$ According to information published by the German Bundestag in Drucksache 17/12339, http://dipbt.bundestag.de/dip21/btd/17/123/1712339.pdf.
} 
system. The Restructuring Fund is managed by the Federal Agency for Financial Market Stability (Bundesanstalt für Finanzmarktstabilisierung; FMSA), in association with the German Federal Ministry of Finance (Bundesministerium der Finanzen). The FMSA can use these funds for public guarantees, recapitalizations, and financing bridge banks.

The annual bank levy reflects the statement from the immediately preceding accounting year; our empirical approach thus exploits the fact that banks could not adjust their annual statements when the levy had been introduced for the first time. That is, the levy was an exogenous tax, applied retrospectively. Annual payments are calculated on the basis of contribution-relevant liabilities, which are subject to a progressive rate, plus a second component resulting from derivative exposures multiplied by a constant factor, as defined in the Restructuring Fund Regulation (Restrukturierungsfonds-Verordnung; RStruktFV). The accounting rules follow the German Commercial Code (Handelsgesetzbuch) rather than international financial reporting standards.

The Restructuring Fund Act (Restrukturierungsfondsgesetz; RStruktFG) came into force in December 2010, as part of the German Restructuring Act (Restrukturierungsgesetz). Whereas the latter focuses on the reorganization of banks in distress (through recapitalizations, guarantees, or bridge banks), the former determines the establishment of a restructuring fund financed by bank levies. Concrete details about the design of the bank levy are available in the Restructuring Fund Regulation, which passed in July 2011.

The legislation process featured controversial debates about how the regulation should be implemented, which created substantial uncertainty about the concrete implementation of the bank levy. This uncertainty implied that each individual bank could not adjust its activities ex ante and thus would be affected by the levy exogenously. For example, one argument suggested that smaller banks did not trigger the crisis but accounted for a notable share of loans to small and mid-sized enterprises. Therefore, there was intense discussion about providing an exemption to savings banks; the minimum threshold was lowered from $€ 500$ to $€ 300$ million, and the acceptability limit was raised from $15 \%$ to $20 \%$ of annual earnings. Furthermore, some discussion focused on whether the regulation should be based on quantity alone or also impose risk weights.

\subsection{Calculating the Bank Levy}

The bank levy reflects the specific liability positions of banks and their derivative exposures. The contribution-relevant liabilities are those defined in section 340a of the German Commercial Code, less the (1) liabilities toward customers excluding liabilities issued as bearer securities (Passivposten 2), (2) profit participation rights with a maturity of more than two years (Passivposten 10), (3) reserve funds for general banking risk (Passivposten 11), and (4) equity (Passivposten 12). The calculation of the contribution-relevant liabilities can be summarized as follows: 
All liabilities according to the annual statement of the immediately preceding accounting year ending before March 1 of the contribution year

- liabilities toward customers, excluding liabilities issued as bearer securities

(Passivposten 2)

- profit participation rights with a maturity of more than two years (Passivposten 10)

- reserve funds for general banking risk (Passivposten 11)

- equity (Passivposten 12)

$=\underline{\text { contribution-relevant liabilities }(L)}$.

The levy imposes a tax on funding sources other than customer deposits and bank equity. It increases progressively with the volume of a bank's contribution-relevant liabilities. In this regard, the German system differs from those established in most other European countries, which impose a flat tax rate on banks of different sizes. If the resulting contribution-relevant sum is smaller than or equal to $€ 300$ million, no levy applies to this component of the tax. Contribution-relevant liabilities $(L)$ exceeding this value are subject to a progressive tax rate, according to the scheme in Figure 1.

However, two liability positions are treated differently: those toward other credit institutes that reflect development loans transactions (Passivposten 1) and trust liabilities counting as development loans (Passivposten 4), both of which are multiplied by 0.0001. After 2012, these positions were no longer subject to the levy and get subtracted from the contributionrelevant liabilities.

The tax payment resulting from derivatives, or the second component on which the levy is based, is calculated as follows: Contribution-relevant derivatives refer to the aggregate notional volume of derivatives listed in the appendix of the last annual account and specified in section 36 of the Credit Institution Accounting Regulation (KreditinstitutsRechnungslegungsverordnung; RechKredV). The accrued levy results from the multiplication of this amount by a factor of 0.000003 .

The final contribution is the sum of the contribution-relevant liability positions, multiplied by the respective factors, and the amount referring to derivative exposures. In special cases, the levy can be capped if an upper bound is reached, or additional charges might be added. By imposing a cap on payments, Germany differs from most other European countries.

\subsection{Upper Bounds and Minimum Contributions}

The regulatory design of the German bank levy allows for both lower and upper bounds on the contribution a bank must pay. The maximum levy to be paid is limited to $20 \%$ of the bank's annual earnings, which corresponds to an acceptability limit (Zumutbarkeitsgrenze). Annual earnings are adjusted for transfers due to profit-and-loss transfer agreements. An additional adjustment takes place if the annual account of a legally non-independent institute, which is not subject to the levy (Restructuring Fund Act, Section 2(2)), becomes part of the 
annual account of a credit institute. If the acceptability limit is reached, the difference between the regularly calculated levy and the actually charged levy can be collected in subsequent years, added to the annual contribution. However, the annual payment resulting as the sum of these two positions must never exceed the acceptability limit of $20 \%$ of annual earnings.

In addition to the annual levy, the FMSA can charge special contributions if the total amount of the levy obtained from all banks is insufficient to finance the rescue fund. The special contribution is proportional to the annual contribution of a bank relative to the total amount of collected levies, both averaged over the previous three years. It cannot be higher than three times the average of a credit institute's annual contributions due during the previous three years. The total amount of special contributions and annual payments is limited to $50 \%$ of the average of the three preceding annual earnings, which corresponds to the so-called capacity limit (Belastungsgrenze). The ultimate upper bound of the annual payment is thus determined by the lower limit of either the acceptability or the capacity limit.

The lower bound or minimum contribution (Mindestbeitrag) corresponds to a minimum of $5 \%$ of the calculated annual contribution. The minimum contribution is paid even if a credit institute has no annual surplus and irrespective of the upper bound.

\subsection{Banks Affected}

All credit institutions that hold a German banking license and are subject to the Credit Institution Accounting Regulation must pay the bank levy. Bridge banks, defined as banks established by the FMSA to resolve banks in distress, and development banks (Förderbanken) such as the Reconstruction Loan Corporation (KfW) are excluded from the levy. In 2011, the banks exempted from the levy accounted for $5.6 \%$ of total assets and $1.9 \%$ of total customer deposits of the German market.

Because the levy is computed on the basis of non-consolidated, single-entity accounts, domestic and foreign branches of German banks are subject to it. ${ }^{2}$ The levy also applies to any subsidiary of foreign banks located in Germany with a German banking license. Foreign subsidiaries of German banks are excluded from the regulation, unless they fall under the classification of the KWG and hold a German banking license. Branches of non-German banks are exempted from the regulation if they belong to credit institutions in the European Economic Area (KWG section 53b). In contrast, branches and subsidiaries of non-German, non-EU banks pursuant to the KWG section $53 \mathrm{c}$ are charged.

\footnotetext{
${ }^{2}$ To avoid double taxation of foreign branches of German banks abroad, Germany signed bilateral agreements with individual countries (e.g., the United Kingdom). Bank levy payments made in Germany thus are deductible from similar payments made abroad.
} 


\subsection{Implications of the Design of the Bank Levy}

The design of the German bank levy gives rise to several considerations. First, it is not a tax in the strict sense but rather a mandatory fee charged to finance the rescue fund. ${ }^{3}$ In contrast with a deposit insurance fund that insures depositors of all banks, the rescue fund is designed to intervene only if systemically important banks are in distress. Although all banks are obliged to pay the levy (unless they fall under the $€ 300$ million liability limit), smaller institutions contribute to the fund but are unlikely to benefit from it directly.

Second, liabilities toward customers and equity are excluded from contribution-relevant positions. This avoids the possibility that banks make contributions twice, with respect to both deposit insurance and the bank levy, and mitigates conflicts with capital regulation. It also provides incentives for banks to switch to more retail-based funding. With our short time window for analysis, we do not expect to find significant effects of the levy on structural adjustments in banks' business models though.

Third, contribution-relevant liabilities are subject to a progressive rate: Larger institutions contribute relatively more. This design imposes higher charges on banks that are more likely to be systemically important, due to their size (too-big-to-fail) or interconnectedness (tooconnected-to-fail). Hence, we expect stronger effects of the levy on banks that are taxed more.

Fourth, the levy increases with the notional value of derivatives. This presumes that banks with a higher volume of derivative trading are more risky; the potential beneficial effects of derivatives are disregarded.

In summary, credit institutes with a market- rather than a retail-based funding strategy and credit institutes involved in derivative trading should be more powerfully affected by the bank levy. Smaller banks, focused on traditional business models, instead may be relatively less affected.

\section{Data and Descriptive Statistics}

Our empirical analysis seeks to answer two main questions. First, which banks have paid the bank levy, and how do these payments relate to bank-specific features? Second, has the levy affected the behavior of banks? We analyze whether banks increased interest rates on new loans, lowered deposits rates, or cut back on lending to compensate for their higher funding costs.

To do so, we use supervisory data provided by the Deutsche Bundesbank on banks' balance sheets, income statements, and prudential indicators for the years 2003-2011. This time window enables us to analyze the behavior of banks preceding the introduction of the levy

\footnotetext{
${ }^{3}$ We use the terms "levy" and "tax" as synonyms to refer to the German bank levy.
} 
(2003-2010) versus their subsequent behavior (2011). All the results are based on annual data as we suspect that changes in banks' behavior take place rather gradually. Furthermore, most of our results are robust to a shorter pre-levy time window (2008-2010).

To focus on banks' adjustments in immediate response to the introduction of the levy, we base our main regression results on a subsample of banks reporting to the MFI interest rate statistics. For these approximately 200 banks, this data set provides information about the quantity of new loans, the interest rate charged across new loans, and interest rates paid for new deposits. ${ }^{4}$ To detect possible differences between the MFI banks and the German banking system as a whole, we provide the descriptive statistics separately for each group.

\subsection{Data Used to Calculate the Bank Levy}

An evaluation of the German bank levy in principle can draw on three data sources. First, we could use the annual reports of the credit institutions, which would provide information about the actual payments of each bank and key banking indicators. However, not all German banks publish annual reports such that the data set would be restricted to publicly listed banks. Confidential regulatory information, collected by supervisors, also would not be available.

Second, the FMSA collects bank levies and therefore has original data about payments by each bank. However, these data are not available to external researchers; they also do not contain additional information about the banks' balance sheets and prudential indicators.

Third, the data collection strategy we use gathered confidential data from the Deutsche Bundesbank pertaining to banks' balance sheets, income statements, and prudential indicators. In Germany, banking supervision is a cooperative effort between the banking supervisor BaFin (Bundesanstalt für Finanzdienstleistungsaufsicht) and the Bundesbank, in which the Bundesbank collects the relevant data. In terms of coverage, quality, and depth, the Bundesbank data thus are the most comprehensive available, including information about the smaller savings banks and credit unions that dominate the retail market. However, these data lack direct information about the levies actually paid by banks. By combining information on the legal rules of how to calculate the levy with high-quality information on banks' balance sheets and income statements, we can calculate the contributions of banks with a sufficient degree of precision though.

The amount actually paid by the bank and the amount we calculate may differ for three reasons. First, instead of development loans, which do not have a direct counterpart in the Bundesbank's reporting scheme, we use the amount of trust liabilities as a proxy. Second,

\footnotetext{
${ }^{4}$ The regression results reflect a balanced sample of banks reporting to the MFI interest rate statistics since 2003. Hence, the sample of banks is constant over time, and we cannot model a possible selection effect. The results are robust to the addition of approximately 40 banks, required to report only since 2010. For a detailed description of the bank selection procedure and the changes introduced to the MFI interest rate statistics in June 2010, see the Deutsche Bundesbank Monthly Reports (January 2004, pp. 47-62; June 2011, pp. 49-62).
} 
data on derivatives held by banks is not available for all banks within the sample. Instead we resort to the over-the-counter (OTC) derivatives statistics, which contain information about banks with derivative exposures of more than $€ 1,000$ billion. Third, to avoid double taxation of banks in the same group, annual earnings are subject to adjustments that cannot be retraced with the available balance sheet and income statement data. Despite these potential deviations, our calculations are very similar to the publicly available information on bank levies (which we present subsequently in Table 3), which increases confidence in the validity of our approach.

\subsubsection{Contribution-Relevant Liabilities}

Contribution-relevant liabilities can be calculated directly from the balance sheets reported to the Bundesbank. These liabilities sum up to $€ 4.7$ trillion across all banks at the end of 2010 , which provides the basis for calculating the 2011 bank levy. Table 1 depicts the distribution of contribution-relevant liabilities across banking groups (Panel a includes the full sample, and Panel $b$ features the sub-sample of MFI banks). We define bank groups such that head institutes of savings banks (Landesbanken) and credit unions (Genossenschaftszentralbanken) combine in one group. Neither mortgage banks nor building societies individually is a focus of our analysis, so we group them together.

The last two columns of Table 1, Panel a, show that the majority of banks have less than $€ 300$ million of contribution-relevant liabilities. More than $77 \%$ of all German banks, and in particular the credit unions, fall below this threshold. The large commercial banks and head institutes of savings banks and credit unions account for more than $73 \%$ of total contributionrelevant liabilities (Column 2). The banks reporting to the MFI interest rate statistics represent the bulk of the contribution-relevant liabilities ( $€ 4.3$ out of $€ 4.7$ trillion). Column 3 indicates the ratio of contribution-relevant to total liabilities; reflecting their weaker retail depositor base, the large commercial banks $(60 \%)$ and head institutes of savings banks and credit unions (75\%) display the largest ratios of taxable liabilities. These ratios are again similar when comparing the two groups for the MFI and the full sample.

To find any indications that banks adjusted the structure of their liabilities in response to the introduction of the levy, in Figures 2 and 3, we compare the amount of contribution-relevant liabilities for 2011 and 2012. Figure 2 plots the contribution-relevant liabilities for 2011 against those of 2012, by bank group. In the left panel, we find that the amount of contribution-relevant liabilities barely changed across years indicating that the banks did not adjust their balance sheets significantly. Inspecting the contribution-relevant liabilities relative to total assets in the right panel of Figure 2 yields similar results. This is not surprising, considering that most banks had contribution-relevant liabilities below $€ 300$ million, which excluded them from payments. However, even for large commercial banks (bank group 1) or 
head institutes of savings banks and credit unions (bank group 3), no significant adjustments arose.

The distribution of contribution-relevant liabilities in the second interval ( $€ 300$ million $<L \leq$ $€ 10$ billion) confirms this finding. Had there been a significant effect of the bank levy, banks would have tried to reduce their contribution-relevant liabilities to below the $€ 300$ million threshold. Yet Figure 3 shows that the share of banks coming close to the threshold did not change substantively between 2011 and 2012. Therefore, in the short time window since the introduction of the tax, no significant changes in banks' business models seem to have taken place. In addition, we performed Kolmogorov-Smirnov tests to compare the distribution of each non-contribution relevant position (e.g., customer deposits or equity) underlying the computation of the bank levy for 2011 and 2012. We do not report these results, for the sake of brevity, but they showed that the bank levy had no significant effect on the balance sheet structure of banks; banks did not actively change their business model to reduce the size of their levy.

\subsubsection{Development Loans and Trust Liabilities}

Development loans (positions 1 and 4) have no direct counterpart in the Bundesbank's reporting scheme. As a proxy, we use the amount of trust liabilities. ${ }^{5}$ Even though this proxy might not be perfect, it should not affect our results much. Column 4 of Table 1 shows that trust liabilities account for only $0.35 \%$ of total liabilities. The impact on the final tax payment is thus negligible.

\subsubsection{Derivative Positions}

Data about the derivatives of banks are not directly available. The year 2008 is the last year in which derivatives data were reported, according to $\$ 36$ of the accounting regulation for all banks. To obtain derivative positions, we resort instead to the OTC derivatives statistics, which reveal the derivative positions of banks, as reported to the Bank for International Settlements (BIS). Only banks with nominal derivative exposures of more than $€ 1,000$ billion must report their exposures to the BIS. In 2010 and 2011, five German banks fell into this category and we refer to them as BIS banks.

The OTC derivative positions provide a useful approximation for calculating the bank levy, for three reasons. First, in 2008, more than $90 \%$ of the overall derivative exposure was accounted for by the BIS banks. Second, among the BIS banks, the OTC derivatives accounted for almost $80 \%$ of total derivative exposures. Third, the OTC derivative exposure

\footnotetext{
${ }^{5}$ Development loans are not restricted to the "trust liabilities" position considered here. Instead, they could be included in the "liabilities vis-à-vis banks" or "other liabilities vis-à-vis non-banks" positions; the trust liabilities position might also contain positions that do not count as development loans.
} 
of the BIS banks was almost unchanged between 2008 and 2010 (Figure 4). Assuming that these results represent the general pattern of banks' derivative exposures, and applying the tax rate to the derivative exposure of non-BIS banks in 2008, we find that the effect on the size of the bank levy of a non-BIS bank would have been negligible.

\subsubsection{Results from the Calculation of the Bank Levy}

Table 2 shows the results from calculating the bank levy. We distinguish the total payments by bank group, the average payments per bank, and the number of contributing banks. We present this information for both the full sample and the sample of MFI banks. As these results reveal, the large commercial banks and head institutes of savings banks and credit unions are the largest contributors. Together, their contributions account for more than $79 \%$ of total revenues from the bank levy; the share increases to more than $82 \%$ for the subsample of banks reporting within the scope of the MFI interest rate statistics. This result is consistent with the finding that these banks had the largest share of contribution-relevant liabilities.

According to Column 1, the total revenue of the bank levy in 2011 across all contributing banks summed to $€ 529$ million. The average contributing bank pays about $€ 1.3$ million. The majority of German banks pay no levy at all though, and in 2011, overall proceeds from the tax were small, accounting for only $3.7 \%$ of the banking system's profits. Of the 1,803 banks in our data set in 2011, only 81 were subject to the acceptability limit, according to our calculations. This limit constitutes the upper bound for a bank's contribution. If we were to ignore the acceptability limit, the total contribution across all banks would have been $€ 1.9$ billion, or more than four times higher. Considering the sample of MFI banks only, the revenues are similar ( $€ 504$ million), with higher average contributions for each bank (€3.4 million), because the MFI banks are above-average in size (see Table 6).

Because we calculate, rather than observe, the payments by each bank, the quality of our approximation method is crucial. In Table 3 we compare the results from our calculation of the bank levy with numbers from official government sources. There are some deviations in the absolute contributions for the group of commercial banks and head institutes of the savings bank sector. Yet the relative contributions of each bank group to the total revenues of the bank levy are close to the numbers published by the government. The deviations in the absolute values might arise because we lack data about the derivative exposures of all banks. Especially within the commercial banking sector and among head institutes of the savings banks and credit unions, some derivative exposures might fall below the threshold of the OTC derivatives statistics.

On average though, the derivative exposures of a bank play only minor roles in determining the individual bank levy. Ignoring the bounds affecting the payments and considering only banks reporting to the BIS, we find that almost $90 \%$ of the total bank levy is attributable to contribution-relevant liabilities. Using 2008 data on the nominal derivative exposure of non- 
BIS banks to approximate derivative positions in 2010, we determine that approximately $35 \%$ of the bank levy would have been attributable to contribution-relevant liabilities and $65 \%$ to the nominal derivative exposure. The reason is that non-BIS banks are mostly small banks that do not have contribution-relevant liabilities of more than $€ 300$ million. Their obligation to pay the bank levy thus would be based solely on their derivative positions. If we consider only those non-BIS banks with contribution-relevant liabilities of more than $€ 300$ million, the fraction of tax payments due to nominal derivatives declines to less than 4\%. Quantitatively, the average effect of the contribution arising from derivatives is of minor importance for the average German bank.

\subsubsection{How Does the Bank Levy Relate to Bank Characteristics?}

One of the objectives behind the introduction of the bank levy is to charge higher levies on banks that impose negative externalities on systemic stability. Larger banks and more interconnected banks tend to be systemically more important (e.g., Altunbas et al. 2011; Arinaminpathy et al. 2012; Drehmann and Tarashev 2011, 2013; Haldane 2012).

Table 4 relates the bank levy to bank sizes and other characteristics that might influence bank stability. The design of the tax makes it unsurprising to observe a positive relationship between bank size and tax payments. This is in line with the finding of Schweikhard and Wahrenburg (2013). If we assume bank size is a reasonable indicator of the risk of a bank and its contribution to systemic risk, this result supports the design of the levy. The correlations by bank group in Table 4 reveal that the high correlation with bank size is driven by savings banks and credit unions; the correlations are lower for large commercial banks or head institutes of savings banks and credit unions, for which the levy is more likely to be capped by the acceptability limit. Considering the share of funding through customer deposits, we find a negative relationship with tax payments. This arises because customer deposits constitute a non-contribution-relevant balance sheet position and the objective of the bank levy is to tax market-based funding and implicitly leverage. For all other variables, the correlations are small. Again, the patterns in the data are similar for both the full sample and the subsample of MFI banks.

\subsection{Data on Bank Loans and Interest Rates}

In the short run, the most important channel of adjustment to the introduction of the bank levy is an increase in lending rates or a reduction in loans. Figures 2 and 3 already showed that there was little evidence of a structural adjustment of funding sources, which is reasonable, considering the short time period. Yet even in the short run, banks might react by changing deposit rates, even if the net effect is not clear. On the one hand, higher deposit rates might attract new customer deposits and funds exempted from the tax. On the other hand, lower deposit rates would compensate for higher funding costs through the levy. 
To obtain information on banks' interest rates on new loans and new deposits, we resort to the Bundesbank's MFI interest rate statistics. These statistics cover lending to and borrowing from the private non-financial sector such that we can analyze the effects of the bank levy on interest rates and new loans. We complement these data with balance sheet information on loans and assets. To assess the impact of the levy on loans, we use four variables: (1) log of new loans from the MFI interest rate statistics, (2) log of total loans (stocks from the balance sheet statistics), (3) total loans scaled by a bank's total assets, and (4) log changes in the stock of loans. Interest rate data on new loans are available for all new loans issued by banks, as well as for loans with short-term (less than 1 year), medium-term (1-5 years), and long-term (over 5 years) maturity. In addition, we have interest rate data on new deposits for all newly received deposits, disaggregated by maturity (i.e., overnight, short-term (less than 1 year) or medium-term (over 1 year) deposits).

Table 5 contains summary statistics for these variables, for all banks and for only the banks reporting to the MFI interest rate statistics. The latter set shows significantly higher mean loans of $€ 20,000$ million, versus $€ 2,193$ million for the full sample. The results obtained from the MFI interest rate statistics thus are representative of larger banks in the market. Smaller banks (exempted from the levy anyway) are underrepresented in this sample. Nevertheless, the two groups of banks are similar in their other structural characteristics: The ratio of loans to total assets is almost identical (70\%), as is the average annual growth rate of loans (Table 5). Table 6 also contains a comparison of key bank characteristics, such as capital and liquidity ratios or profitability, and affirms their similarity.

\subsection{Bank-Level Control Variables}

We calculate the bank-level control variables on the basis of the CAMEL rating system, as employed by regulators in the United States to assess the overall state of a bank. We use data on individual banks' balance sheets, income statements, and supervisory information to construct variables that proxy for capital adequacy $(C)$, asset quality $(A)$, management quality $(M)$, earnings $(E)$, and liquidity $(L)$.

Because we have access to supervisory information, we obtain high quality data about a bank's level of Tier 1 capital relative to risk-weighted assets which constitutes our capital adequacy variable (Tier 1 capital ratio). ${ }^{6}$ To proxy for the quality of a bank's asset portfolio, we resort to a bank's write-offs relative to the size of its overall loan portfolio (non-

\footnotetext{
${ }^{6}$ Before 2007, a bank's Tier 1 capital ratio was calculated as the ratio between Tier 1 capital and risk-weighted assets. Since 2008, it has been calculated relative to the own funds requirements (Eigenmittelanforderungen) of a bank. During the transition period in 2007, banks could choose to report either risk-weighted assets or own funds requirements. Ex-post, we cannot differentiate whether a bank reported according to the pre-2007 or post-2007 reporting standard. Therefore, we chose not to calculate a Tier 1 capital ratio for 2007.
} 
performing loans [NPL] ratio). ${ }^{7}$ To measure the quality of a bank's management team, we use the cost-to-income ratio. Return on assets $(R o A)$ serves to measure the profitability of the bank. Finally, the sum of cash, deposits with the central bank, and overnight deposits relative to total assets provides a proxy of the liquid resources of a bank (liquidity ratio). In addition, we control for bank size by including the logarithm of total assets.

Table 6 contains summary statistics for these variables for all banks in the sample, from 2003 to 2011. To winsorize the CAMEL variables, we replace the highest and lowest $1 \%$ of observations with the respective thresholds. For the cost-to-income ratio, only the highest $1 \%$ of all observations is replaced. Banks with missing values for total assets are excluded from the sample.

Information on the subset of banks in the MFI interest rate statistics appear in the right panel of Table 6. The main difference between the two samples of banks is that the MFI banks are larger, with mean assets of $€ 34.80$ billion, compared with $€ 3.66$ billion for the full sample.

\section{Regression Results}

Did German banks reduce the amount of (newly issued) loans to the private sector after the introduction of the bank levy? Did treated and non-treated banks adjust loan and deposit rates differently? To answer these questions, we analyze whether key activities of banks changed after the implementation of the levy in 2011, and we compare treated and non-treated banks. We employ a difference-in-difference approach to exploit the variation over two dimensions: the times before and after the introduction of the bank levy and banks that had to pay and those that did not.

\subsection{Baseline Empirical Model}

A difference-in-difference approach requires two conditions. First, the introduction of the bank levy should not have been anticipated by the banks; otherwise, they could have adjusted their balance sheets before the introduction of the tax to pay smaller contributions or evade the tax entirely. In this case, the effects on banks' activities resulting from the imposition of the levy could not be identified. We exploit the substantial uncertainty surrounding the implementation of the tax, in terms of the banks that would be covered and the precise specification of the tax payments. In addition, the levy was applied in retrospect to banks' balance sheets. As discussed in detail in Section 2.1, the German bank restructuring law passed in December 2010, the regulation was approved in July 2011, and by August 2011, banks had to deliver, for the first time, information about their tax base, according to their 2010 balance sheet data.

\footnotetext{
${ }^{7}$ Before 2009, only loans to the non-financial private sector with specific provisions were considered; after 2009, loans to both the financial and non-financial private sectors were included.
} 
Second, we must assume that differences in the means between the control and the treatment group would have remained constant, without this change in regulation. In the absence of the treatment, the trend between the two groups should have remained the same. Hence, any differences in the behavior of banks in the control versus treatment group should be due solely to the tax. This common trends assumption cannot be tested; ideally, banks in the control and the treatment group show similar characteristics. To control for confounding factors and remaining differences across banks in the two groups, our empirical model allows for time and bank-fixed effects, as well as bank-specific controls. Furthermore, according to Figure 5, before the introduction of the levy, the loan volumes and interest rates of banks in both control and treatment group evolved similarly.

With these assumptions, our baseline regression equation thus is:

$$
y_{i t}=\alpha_{i}+\gamma_{t}+\delta^{*} \text { ChargedBank } * \text { After 2010+ } \beta^{\prime} x_{i t-1}+\varepsilon_{i t}
$$

where the dependent variable $y_{i t}$ refers to bank loans or bank interest rates. We include timeinvariant bank fixed effects $\left(\alpha_{i}\right) ; \gamma_{t}$ captures time effects common to all banks. Charged Bank is an indicator variable, equal to 1 if the bank is subject to the tax (i.e., has contributionrelevant liabilities higher than $€ 300$ million) and 0 otherwise. After 2010 is an indicator variable taking a value of 1 after the regulatory change (2011) and 0 otherwise (2003-2010). We define $x_{i t-1}$ as a vector of controls for time-varying bank characteristics, lagged by one period to avoid simultaneity. The coefficient of interest is $\delta$, which reveals whether banks subject to the tax changed their behavior significantly after the change in regulation compared with banks that fall below the contribution threshold.

Tables 7-9 show the results for estimating Equation (1) and pooling the data across all banks reporting to the MFI interest rate statistics. We distinguish results for loans (Table 7), interest rates on new loans (Table 8), and interest rates on new deposits (Table 9). For the interest rates, we also analyze different maturities. For the sample of MFI banks, there is no significant effect of the bank levy on loans or interest rates. Banks that must pay the levy did not change their behavior significantly compared with banks in the control group. These results are robust to considering only post-crisis observations since 2008 or simply testing differences in means across banks in the control and treatment group and the years 2010 (before the introduction of the bank levy) and 2011.

With regard to the impact of the control variables, lending increases with bank size. This effect is non-linear and levels off as banks grow larger. Larger banks also charge lower loan rates and pay higher deposit rates. Again, the effect is non-linear and reverses for larger banks. Most CAMEL variables are insignificant, suggesting that differences across banks are absorbed largely by the bank fixed effects. If anything, more profitable banks lend more. The higher the share of non-performing loans in the portfolio and the less efficiently a bank is managed, which implies a higher cost-to-income ratio, the lower are loans. 
The result that the bank levy has no significant impact on bank behavior is not very surprising. After all, only a few banks actually pay the levy, and the final payments are small. We therefore explore whether banks that are affected more by the levy-because they have higher market shares or pay higher levies - change their behavior. For the former, we measure the pricing power of banks simply by asking whether banks with a higher market share (and thus presumably greater pricing power) react more to the levy (Section 4.2). We then employ a similar difference-in-difference model as above but distinguish banks with high versus low contribution-relevant liabilities (Section 4.3).

\subsection{Impact of Banks' Market Shares}

The response of banks to the levy may depend not only on whether they pay levies but also on their market power and their ability to roll over higher funding costs. Banks with higher market shares might find it easier to maintain loan supplies, despite increased funding costs. These banks might also be able to shift higher costs to their customers by increasing loan rates and/or lowering deposit rates. To identify whether the relative asset position of a bank in the market affects its behavior in response to the bank levy, we run the following regression:

$$
\begin{aligned}
& y_{i t}=\alpha_{i}+\gamma_{t}+\delta^{*} \text { ChargedBank } * \text { After 2010+ } \theta^{*} \text { ChargedBank } * \text { After 2010* } \\
& \text { MarketShare }_{i, \text { mean } 03-10}+\beta^{\prime} x_{i t-1}+\varepsilon_{i t}
\end{aligned}
$$

which includes an additional interaction term between the indicator variable for being treated after 2010 and the market share averaged over the period 2003-2010. ${ }^{8}$ We deliberately choose a long time window to calculate the market shares of banks, because we want to avoid capturing the short-run impact of the crisis. A bank's market share is the total assets $a_{i t}$ of bank $i$ relative to the sum of total assets of all banks in the data set at time $t$, that is, MarketShare $_{i t}=a_{i t} / \Sigma_{i=[1, \ldots, N]} a_{i t}$.

Table 10 displays the regression results using the loans as the dependent variable. Consistent with previous results, banks subject to the levy do not differ significantly in their lending decisions compared with non-treated banks. However, the interaction term between a bank's market share and the bank levy dummy is significant: Banks subject to the bank levy in 2011 and with a higher market share provide fewer loans relative to banks that did not pay the tax. The significance of this finding is limited to regressions that focus on the level of the loan stock, whether the total lending volume (Column 2) or the size of the loan portfolio relative to a bank's assets (Column 3) is used as the dependent variable. This result might suggest the cancellation of old, non-profitable loans. In unreported regressions, we split the sample by bank group and find that the result is driven mainly by the savings banks and credit unions, as well as their head institutes. Focusing on this group of banks, we find a significant, negative

\footnotetext{
${ }^{8} \mathrm{We}$ did not include market shares in the previous regressions, because they are highly correlated with total assets.
} 
effect for both the total loan portfolio and the lending decision with respect to newly issued loans. ${ }^{9}$

Table 11 reveals that banks subject to the levy and with a higher market share charge higher loan rates than banks in the control group. The result holds in particular in cases in which we do not differentiate between maturities and for short-term loans. Focusing on deposit rates, we can see from Table 12 that banks paying the tax and that are larger in relative size offer lower interest rates for new overnight deposits and deposits with a maturity of up to one year, relative to banks in the control group.

\subsection{Impacts of the Size of the Bank Levy}

A larger market share correlates positively with bank size such that the results in Section 4.2 might capture not only the effects of the greater pricing power of banks but also higher tax payments. In this section, we thus test whether differences in the responses of banks to the levy are linked to the absolute size of the payment. We compare differences in the adjustment across banks that meet different thresholds for contribution-relevant positions. We again use a difference-in-difference approach but focus only on banks with contribution-relevant liabilities higher than $€ 300$ million. Thus, we can compare banks that represent higher intervals with banks that fall under lower thresholds, implying lower tax rates. Otherwise, the identification is identical: We compare the times before and after the introduction of the bank levy. The regression equation also is similar:

$y_{i t}=\alpha_{i}+\gamma_{t}+\delta^{*}$ ChargedBank $_{\text {high }} *$ After $2010+\beta^{\prime} x_{i t-1}+\varepsilon_{i t}$

Here though, our interest is in the coefficient $\delta$ of the interaction term Charged Bank high * After 2010, where Charged Bank high is an indicator variable that takes a value of 1 if the bank meets the contribution threshold above $€ 10$ billion or 0 if the bank's contribution-relevant liabilities are higher than $€ 300$ million but smaller than or equal to $€ 10$ billion. Alternatively, we could control directly for the size of the tax payment. However, as we lack full information on the relevant positions to be taxed, doing so might cause a measurement bias. In contrast, we have all necessary data to compute contribution-relevant liabilities such that constructing a dummy based on this component eliminates such concerns.

In Tables 13-15, we present the regressions, as specified in Equation (3). This sample includes only those banks with contribution-relevant liabilities greater than $€ 300$ million, based on December 2010 balance sheet data. Within this sample, we analyze whether the effect of the bank levy changes with the size of contribution-relevant liabilities. Finding a significant coefficient for the term Charged Bank high * After 2010 for example would suggest that banks subject to higher tax rates react differently than banks with smaller contributionrelevant liabilities.

\footnotetext{
${ }^{9}$ For brevity, these results are not reported here but can be obtained on request.
} 
The results in Table 13 show a significant, negative impact on the total loan supply: Banks with contribution-relevant liabilities of more than $€ 10$ billion provide fewer loans than banks with liabilities below this threshold. The coefficient estimate for log loans $(-0.13)$ indicates that loans increased, on average, by $13 \%$ less for banks subject to higher tax rates than for banks with low contribution-relevant liabilities. Splitting the sample by bank group reveals that this finding is due mainly to savings banks and credit unions and their head institutes. Accounting for differences in the size of the levy paid did not affect loan rates (Table 14) while we find a negative impact on deposit rates (Table 15).

\section{Conclusion}

This research has assessed the effects of the German bank levy, imposed for the first time in 2011. It aims to internalize the systemic risk of banks and finance a bank restructuring fund. Similar levies are currently being discussed in various regulations for bank restructuring and resolution throughout Europe. Hence, the findings pertaining to the German bank levy might bear interesting insights for a larger policy debate too.

In this paper, we have constructed data about payments by individual German banks, on the basis of confidential bank-level information provided by the Deutsche Bundesbank. The results show that the majority of German banks (77\%) were exempt from paying the tax because of their small size. The bulk of the tax payments came from large commercial banks and head institutes of savings banks and credit unions. The overall proceeds from the tax have been small, accounting for only 3.7\% of the banking system's profits in 2011 .

In terms of the effects of the levy, we find no significant impacts on lending behavior or interest rates for the average German bank. However, the effect of the levy on the behavior of a bank appears to depend on its relative position in the market. Banks that contribute to the bank levy and have relatively high market shares provide fewer loans, increase loan rates on new loans, and lower interest rates on new deposits following the introduction of the bank levy. A similar result emerges for banks with a relatively high tax base. 


\section{References}

Albertazzi, U., and L. Gambacorta (2010). Bank Profitability and Taxation. Journal of Banking \& Finance 34(11): 2801-2810.

Altunbas, Y., S. Manganelli, and D. Marques-Ibanez (2011). Bank Risk During the Financial Crisis: Do Business Models Matter? ECB Working Paper Series 1394, European Central Bank.

Arinaminpathy, N., Kapadia, S., and R. May (2012). Size and Complexity in Model Financial Systems. PNAS 109 (45): 18338-18343.

Behn, M., Haselmann, R., and P. Wachtel (2013). Pro-Cyclical Capital Regulation and Lending. NYU Working Paper No. 2451/31847, New York University.

Capelle-Blancard, G., and O. Havrylchyk (2013). The Ability of Banks to Shift Corporate Income Taxes to Customers. Working Papers 2013-09, CEPII Research Center.

Chiorazzo, V., and C. Milani (2011). The Impact of Taxation on Bank Profits: Evidence from EU Banks. Journal of Banking \& Finance 35: 3202-3212.

Damar, H.E., C.A. Meh, and Y. Terajima (2013). Leverage, Balance-Sheet Size and Wholesale Funding. Journal of Financial Intermediation 22(4): 639-662.

Demirgüç-Kunt, A., and H. Huizinga (1999). Determinants of Commercial Bank Interest Margins and Profitability: Some International Evidence. World Bank Economic Review 13(2): 379-408.

Demirgüç-Kunt, A., and H. Huizinga (2001). The Taxation of Domestic and Foreign Banking. Journal of Public Economics 79: 429-453.

De Nicolò, G., A. Gamba, and M. Lucchetta (2012). Capital Regulation, Liquidity Requirements and Taxation in a Dynamic Model of Banking. Discussion Papers 10/2012, Deutsche Bundesbank, Research Centre.

Deutsche Bundesbank (2004). Die neue EWU Zinsstatistik - Methodik zur Erhebung des deutschen Beitrags. Bundesbank Monthly Report (January 2004). Frankfurt a.M.

Deutsche Bundesbank (2011). Die erweiterte MFI-Zinsstatistik: Methodik und erste Ergebnisse. Bundesbank Monthly Report (June 2011). Frankfurt a.M.

Drehmann, M., and N. Tarashev (2011). Systemic Importance: Some Simple Indicators. BIS Quarterly Review, Bank for International Settlements, March.

Drehmann, M., and N. Tarashev (2013). Measuring the Systemic Importance of Interconnected Banks. Journal of Financial Intermediation 22(4): 586-607.

Gottlieb, G., A. Avanova, and G. Impavido (2012). Taxing Finance. Finance and Development 49(3): 44-47.

Haldane, A. (2012). On Being the Right Size. Speech given at the Institute of Economic Affairs' $22^{\text {nd }}$ Annual Series, The 2012 Beesley Lectures at the Institute of Directors, Pall Mall, October 2012.

International Monetary Fund (IMF) (2010). Financial Sector Taxation: The IMF's Report to the G20 and Background Material. Washington DC: IMF.

Laeven, L., and F. Valencia (2012). Systemic Banking Crises Database: An Update. IMF Working Paper 12/163. Washington DC. 
Perotti E., and J. Suarez (2009). Liquidity Insurance for Systemic Crises. CEPR Policy Insight No. 31 February.

Perotti, E., and J. Suarez (2011). A Pigovian Approach to Liquidity Regulation. International Journal of Central Banking 7(4): 3-41.

Reinhart, C.M., and K.S. Rogoff (2011). From Financial Crash to Debt Crisis. American Economic Review 101: 1676-1706.

Reinhart, C.M., and K.S. Rogoff (2013). Banking Crises: An Equal Opportunity Menace. Journal of Banking \& Finance 37(11): 4557-4573.

Schweikhard, F.H., and M. Wahrenburg (2013). The Internalization of Systemic Risk: An Analysis of Bank Levy Schemes. Presented at the EFA 2013 Meetings, Gothenburg.

Shin, H.S. (2010). Non-Core Liabilities Tax as a Tool for Prudential Regulation. Policy Memo: http://www.princeton.edu/ hsshin/www/NonCoreLiabilitiesTax.pdf.

Taylor, A.M. (2012). The Great Leveraging. NBER Working Papers 18290. Cambridge, MA. 


\section{Data Appendix}

The empirical results in this paper are based on bank-level data obtained from the Deutsche Bundesbank. The data are confidential and can be used on the premises of the Deutsche Bundesbank only. We resort to information on banks' regulatory capital (SA3/EUEB), bank lending (SON01/SON05/MFI interest rate statistics), banks' balance sheets (EJB), and banks' profit and loss accounts (EGV). Variables and definitions are listed below; information in brackets refers to the corresponding codes in the Deutsche Bundesbank statistics.

\section{Banking groups}

MFI banks: Group of banks required to report in the context of the MFI interest rate statistics.

Head institutes: Head institutes of savings banks and credit unions.

Mortgage banks: Mortgage banks and building societies.

\section{Information used to calculate the bank levy}

Contribution-relevant liabilities: First tax base of the bank levy; net liabilities of a bank computed according to RStruktFV, to which the respective tax rates are applied to obtain the first component of the bank levy.

Derivatives: Second tax base of the bank levy; amount of derivatives held by a bank; for the calculation of the bank levy, the amount of OTC derivatives held by a bank and reported to the BIS is used as a proxy.

\section{Dependent variables}

Newly issued loans: New loans granted to households and non-financial firms [MFI interest rate statistics].

Loan stock: Loans to banks [EJB_27] plus loans to the private sector (households and firms) [EJB 52].

Loan rates: Volume-weighted interest rates charged on newly issued loans to the private sector (households and non-financial firms) [MFI interest rate statistics].

Deposit rates: Volume-weighted interest rates paid for newly received deposits from the private sector (households and non-financial firms) [MFI interest rate statistics].

\section{Bank-level explanatory variables}

Total assets: Sum of on-balance sheet items, in million $€$ unless indicated otherwise.

Tier 1 capital ratio: Fraction of Tier 1 capital relative to risk-weighted assets, where Tier 1 capital is defined as:

o before 2007: Tier 1 capital [Principle I SA3_420].

o since 2007: Tier 1 capital [Basel II EUEB_096001], due to transition period in 2007 no data available for 2007 ;

and risk-weighted assets (RWA) are defined as: 
o before 2007: RWA [Principle I GB1_05002].

o since 2007: RWA are based on the capital requirements for counterparty risk $\left[12.5^{*}\left(E U E B \_124001+E U E B \_163001\right)\right]$, due to transition period in 2007 no data available for 2007 .

Non-performing loans (NPL) ratio: Fraction of non-performing loans relative to gross loan volume, where gross loan volume before 2009 is given by the gross loan volume [SON01_74], and after 2009, it is the sum of the net loan volume [SON01_74] plus specific loan loss provisions [SON01_412, SON01_418] plus general loan loss provisions [SON01_414, SON01_420] plus untaxed general loan loss provisions [SON01_80] plus direct write-offs [SON01_86]. Non-performing loans before 2009 is the gross loan volume with specific loan loss provisions (excluding loans to financial institutions) [SON05_3]; after 2009, it is the sum of loans with latent risks [SON01_409, SON01_411, SON01_415,SON01_417].

Cost-to-income ratio: Degree by which operating expenses are covered by operating income, where costs are operating expenses $\left[E G V_{-} 3, E G V_{-} 6, E G V_{-} 7, E G V_{-} 8, E G V_{-} 14, E G V_{-} 15\right.$, $\left.E G V_{-} 17\right]$, and income is operating income $\left[E G V_{-} 3 \overline{5}, E G V_{-} \overline{3} 9, E G V_{-} 45, E G V_{-} 46, E G V_{-} 47\right.$, EGV_51].

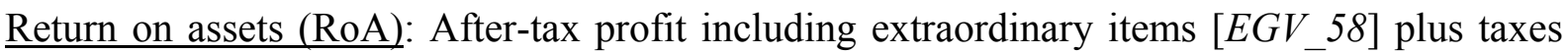
paid [EGV_24, EGV_25] relative to total assets [EJB_128].

Liquidity ratio: Fraction of total assets held in liquid assets, where liquidity is cash [EJB_5] plus central bank balances [EJB_10] plus claims with banks repayable on demand [EJB_ $\overline{1} 1]$ plus securities eligible as collateral at central banks [EJB_81].

Merger dummy: Dummy variable is equal to 1 if a merger took place in a given year during the sample period and 0 otherwise. 


\section{Table 1: Contribution-Relevant Liabilities by Bank Group}

The table shows the amount of contribution-relevant liabilities $(L)$ (in billion $€$ ) for both the full sample of banks and the subsample of banks reporting to the MFI interest rate statistics. Numbers are reported across all banks in the sample, as well as disaggregated by bank group, and refer to the year 2011. In column 1, the contributionrelevant liabilities are summed over all banks within a specific bank group of the respective sample. Contribution-relevant liabilities by bank group as a fraction of the total amount of contribution-relevant liabilities are shown in column 2. The share of contribution-relevant liabilities to total liabilities is reported in column 3. Column 4 gives the share of trust liabilities in total liabilities. The distribution of contribution-relevant liabilities across bank groups for the contribution year 2011 is shown for the full sample of banks only: Columns 4 and 5 of the first panel give the percentage share of banks with contribution-relevant liabilities below or equal to (above) $€ 300$ million. If a bank's contribution-relevant liabilities are smaller than or equal to this threshold, it is exempted from the payment of the bank levy.

(a) Full sample (1,803 bank-year observations)

\begin{tabular}{|c|c|c|c|c|c|c|}
\hline & $\begin{array}{c}(1) \\
\text { Contribution- } \\
\text { relevant } \\
\text { liabilities } \\
\text { (billion } € \text { ) }\end{array}$ & $\begin{array}{c}(2) \\
\% \text { of total } \\
\text { contribution- } \\
\text { relevant } \\
\text { liabilities }\end{array}$ & $\begin{array}{c}\text { (3) } \\
\% \text { of total } \\
\text { liabilities }\end{array}$ & $\begin{array}{c}(4) \\
\text { Trust } \\
\text { liabilities } \\
\text { (\% of total } \\
\text { liabilities) }\end{array}$ & $\begin{array}{c}(5) \\
\text { Banks with } \\
L \leq € 300 \\
\text { million } \\
\text { (\% of total) }\end{array}$ & $\begin{array}{c}(6) \\
\text { Banks with } \\
L>€ 300 \\
\text { million } \\
(\% \text { of total })\end{array}$ \\
\hline Large commercial banks & 2,032 & 43.55 & 60.24 & 0.07 & 0.00 & 100.00 \\
\hline Other commercial banks & 281 & 6.02 & 33.59 & 0.26 & 58.66 & 41.34 \\
\hline Head institutes & 1,390 & 29.80 & 74.80 & 0.67 & 0.00 & 100.00 \\
\hline Savings banks & 252 & 5.39 & 22.95 & 0.14 & 48.02 & 51.98 \\
\hline Credit unions & 141 & 3.02 & 17.43 & 0.35 & 93.67 & 6.33 \\
\hline Mortgage banks & 570 & 12.21 & 36.92 & 0.83 & 31.71 & 68.29 \\
\hline Total & 4,666 & 100.00 & 21.27 & 0.35 & 77.09 & 22.91 \\
\hline
\end{tabular}

(b) Reporting banks in MFI interest rate statistics (165 bank-year observations)

\begin{tabular}{l|c|c|c|c}
\hline \hline & $\begin{array}{c}(1) \\
\text { Contribution- } \\
\text { relevant } \\
\text { liabilities } \\
\text { (billion } € \text { ) }\end{array}$ & $\begin{array}{c}(2) \\
\text { \% of total } \\
\text { contribution- } \\
\text { relevant } \\
\text { liabilities }\end{array}$ & $\begin{array}{c}\text { \% of total } \\
\text { liabilities }\end{array}$ & $\begin{array}{c}\text { (4) } \\
\text { Trust } \\
\text { liabilities } \\
\text { (\%) total } \\
\text { liabilities) }\end{array}$ \\
\hline Large commercial banks & 2,032 & 47.57 & 60.24 & 0.07 \\
Other commercial banks & 171 & 4.01 & 33.01 & 0.03 \\
Head institutes & 1,391 & 32.56 & 74.80 & 0.67 \\
Savings banks & 119 & 2.80 & 23.20 & 0.07 \\
Credit unions & 49 & 1.15 & 18.92 & 0.12 \\
Mortgage banks & 509 & 11.91 & 46.04 & 0.95 \\
Total & 4,271 & 100.00 & 30.84 & 0.34 \\
\hline \hline
\end{tabular}




\section{Table 2: Revenue from the Bank Levy in 2011 by Bank Group}

In this table, we report the total contribution made by all banks in the sample (total levy, in million $€$ ), the average payment (average levy, in million $€$ ), and the corresponding number of contributing banks, which surpass the $€ 300$ million threshold and pay at least the minimum contribution of $5 \%$ of the computed bank levy (Columns 1-3). Columns 4-6 depict the same information for the subsample of banks reporting within the scope of the MFI interest rate statistics. All numbers refer to the contribution year 2011, so the balance sheet data come from 2010, and are reported for the full sample and by bank group.

\begin{tabular}{|c|c|c|c|c|c|c|}
\hline & \multicolumn{3}{|c|}{$\begin{array}{c}(1) \\
\text { Full sample } \\
(1,803 \text { bank-year } \\
\text { observations })\end{array}$} & \multicolumn{3}{|c|}{$\begin{array}{c}(2) \\
\text { Reporting banks in MFI } \\
\text { interest rate statistics } \\
\text { (165 bank-year } \\
\text { observations) }\end{array}$} \\
\hline & $\begin{array}{l}\text { Total levy } \\
\text { (million } € \text { ) }\end{array}$ & $\begin{array}{c}\text { Average levy } \\
(\text { million } €)\end{array}$ & $\mid \begin{array}{c}\text { Number of } \\
\text { contributing } \\
\text { banks }\end{array}$ & $\begin{array}{l}\text { Total levy } \\
\text { (million } € \text { ) }\end{array}$ & $\begin{array}{c}\text { Average levy } \\
(\text { million } €)\end{array}$ & $\begin{array}{c}\text { Number of } \\
\text { contributing } \\
\text { banks }\end{array}$ \\
\hline Large commercial banks & 210.5 & 52.6 & 4 & 210.5 & 52.6 & 4 \\
\hline Other commercial banks & 31.5 & 0.4 & 74 & 17.9 & 1.1 & 17 \\
\hline Head institutes & 206.3 & 17.2 & 12 & 206.3 & 17.2 & 12 \\
\hline Savings banks & 29.3 & 0.1 & 223 & 19.6 & 0.3 & 67 \\
\hline Credit unions & 10.0 & 0.1 & 72 & 8.6 & 0.3 & 27 \\
\hline Mortgage banks & 41.5 & 1.5 & 28 & 40.6 & 2.1 & 19 \\
\hline Total & 529.1 & 1.3 & 413 & 503.5 & 3.4 & 146 \\
\hline
\end{tabular}




\section{Table 3: Revenue from the Bank Levy in 2011 by Bank Group: Comparison with Data} from Governmental Sources

This table compares the total contribution made by all banks in the sample (total levy, in million $€$ ) with numbers from official sources. Columns 1 and 2 refer to all banks that surpass the $€ 300$ million threshold and pay at least the minimum contribution of $5 \%$ of the computed bank levy, based on our own calculations and using balance sheet data collected by the Deutsche Bundesbank. Columns 3 and 4 contain the information published on p. 20 in Drucksache 17/12339 (German Bundestag, Answer by Parliamentary State Secretary Steffen Kampeter dated February 12, 2012).

\begin{tabular}{|c|c|c|c|c|}
\hline & (1) & (2) & (3) & $(4)$ \\
\hline & \multicolumn{2}{|c|}{ Data set, total levy } & \multicolumn{2}{|c|}{ Official data, total levy } \\
\hline & $($ million $€)$ & $(\%$ of total $)$ & $($ million $€)$ & (\% of total) \\
\hline All commercial banks & 242 & 45.7 & 256 & 44.1 \\
\hline Head institutes & 206 & 39.0 & 246 & 42.4 \\
\hline Savings banks & 29 & 5.5 & 28 & 4.8 \\
\hline Credit unions & 10 & 1.9 & 8 & 1.3 \\
\hline Mortgage banks & 42 & 7.8 & 43 & 7.4 \\
\hline Total & 529 & 100 & 581 & 100 \\
\hline
\end{tabular}




\section{Table 4: Correlations between the Bank Levy and Bank Characteristics}

This table shows the correlation between various bank characteristics and the contribution to be made in 2011 . The correlations are based on the contributed bank levy in 2011 (in million $€$ ) and bank characteristics as of 2010 as the tax payment results from balance sheet positions of the annual account corresponding to the year proceeding the contribution year, or 2010. Results are reported for all banks in the sample as well as for the subsample of banks reporting to the MFI interest rate statistics.

(a) Full sample (1,803 bank-year observations)

\begin{tabular}{l|c|c|c|c|c|c|c}
\hline \hline & $\begin{array}{c}(1) \\
\text { Total } \\
\text { assets } \\
\text { (million } € \text { ) }\end{array}$ & $\begin{array}{c}\text { Customer } \\
\text { deposits / } \\
\text { total } \\
\text { liabilities }\end{array}$ & $\begin{array}{c}\text { Loans / } \\
\text { customer } \\
\text { deposits }\end{array}$ & $\begin{array}{c}\text { Tier 1 } \\
\text { capital } \\
\text { ratio }\end{array}$ & $\begin{array}{c}\text { Liquidity } \\
\text { ratio }\end{array}$ & RoA & NPL ratio \\
\hline Large commercial banks & 0.59 & -0.73 & 0.38 & 0.08 & -0.51 & 0.27 & -0.27 \\
Other commercial banks & 0.69 & -0.09 & -0.02 & -0.14 & -0.14 & -0.05 & -0.08 \\
Head institutes & 0.54 & 0.04 & -0.06 & 0.48 & -0.22 & 0.38 & 0.24 \\
Savings banks & 0.93 & -0.22 & 0.20 & -0.13 & -0.10 & -0.10 & -0.08 \\
Credit unions & 0.84 & -0.17 & 0.23 & -0.06 & -0.07 & -0.07 & -0.04 \\
Mortgage banks & 0.71 & -0.56 & 0.15 & -0.38 & -0.12 & -0.24 & -0.09 \\
Total & 0.79 & -0.22 & 0.00 & -0.04 & -0.03 & -0.07 & -0.02 \\
\hline \hline
\end{tabular}

(b) Reporting banks in MFI interest rate statistics (165 bank-year observations)

\begin{tabular}{l|c|c|c|c|c|c|cr}
\hline \hline & $\begin{array}{c}(1) \\
\text { Total } \\
\text { assets } \\
\text { (million } €)\end{array}$ & $\begin{array}{c}\text { Customer } \\
\text { deposits / } \\
\text { total } \\
\text { liabilities }\end{array}$ & $\begin{array}{c}\text { (3) } \\
\text { Loans / } \\
\text { customer } \\
\text { deposits }\end{array}$ & $\begin{array}{c}\text { Tier 1 } \\
\text { capital } \\
\text { ratio }\end{array}$ & $\begin{array}{c}\text { Liquidity } \\
\text { ratio }\end{array}$ & RoA & NPL ratio \\
\hline Large commercial banks & 0.59 & -0.73 & 0.38 & 0.08 & -0.51 & 0.27 & -0.27 \\
Other commercial banks & 0.58 & -0.07 & 0.01 & -0.25 & -0.33 & -0.05 & -0.22 \\
Head institutes & 0.54 & 0.04 & -0.06 & 0.48 & -0.22 & 0.38 & 0.24 \\
Savings banks & 0.93 & -0.42 & 0.34 & -0.36 & -0.09 & -0.48 & -0.01 \\
Credit unions & 0.93 & -0.49 & 0.20 & -0.06 & -0.31 & -0.26 & -0.04 \\
Mortgage banks & 0.74 & -0.63 & 0.07 & -0.45 & 0.09 & -0.41 & -0.01 \\
Total & 0.78 & -0.42 & -0.01 & -0.14 & -0.05 & -0.17 & 0.00 \\
\hline \hline
\end{tabular}




\section{Table 5: Summary Statistics for Loan Volumes and Interest Rates}

The table shows summary statistics for the loan volume, loan rate, and deposit rate variables. Descriptive statistics based on the full sample include all observations from 2003-2011 for all banks in our data set; those based on the subsample of banks reporting within the scope of the MFI interest rate statistics include all observations from this period for banks reporting from 2003 onward. The dependent variable is either newly granted loans ("New Loans," millions €) or the volume of existing loans ("Loans," millions €). "Loans/Assets" gives the fraction of the total loan stock relative to total assets. "Loans (YoY change in \%)" denotes the year-onyear change of the total loan stock. The loan and deposit rates (\%) are end-of-year volume-weighted interest rates. Data on loan rates are available for three maturity brackets. Short-term loan rates are fixed for a maximum of one year. Medium-term loan rates are fixed for at least one year and up to a maximum of five years. Longterm loan rates are fixed for at least five years. "All maturities" is a weighted average of loan rates across the three maturity buckets. Deposit rates are available for three maturity brackets. Overnight deposit rates are paid for deposits with an overnight maturity. Short-term deposit rates are fixed for a maximum of one year. Mediumterm deposit rates are fixed for at least one year. "All maturities" is a weighted average of deposit rates across the three different maturity buckets available. For more details, see the description in the Data Appendix.

\begin{tabular}{|c|c|c|c|c|}
\hline & \multicolumn{2}{|c|}{$\begin{array}{c}(1) \\
\text { Full sample } \\
(15,052 \text { bank-year observations })\end{array}$} & \multicolumn{2}{|c|}{$\begin{array}{c}(2) \\
\text { Reporting banks in MFI interest rate statistics } \\
(1,197 \text { bank-year observations })\end{array}$} \\
\hline & Mean & Std. dev. & Mean & Std. dev. \\
\hline \multicolumn{5}{|l|}{ Loan volume } \\
\hline New loans (million $€$ ) & & & 3.46 & 11.40 \\
\hline Loans (million $€$ ) & 2,193 & 18,300 & 20,000 & 59,300 \\
\hline Loans/Assets (ratio) & 0.70 & 0.13 & 0.70 & 0.14 \\
\hline Loans (YoY change in \%) & 0.03 & 0.19 & 0.02 & 0.11 \\
\hline \multicolumn{5}{|l|}{ Loan rates (\%) } \\
\hline All maturities & & & 4.38 & 1.51 \\
\hline Short-term & & & 4.16 & 1.80 \\
\hline Medium-term & & & 4.97 & 1.28 \\
\hline Long-term & & & 4.99 & 1.42 \\
\hline \multicolumn{5}{|l|}{ Deposit rates (\%) } \\
\hline All maturities & & & 2.16 & 0.92 \\
\hline Overnight & & & 0.98 & 0.62 \\
\hline Short-term & & & 2.02 & 0.97 \\
\hline Medium-term & & & 2.78 & 0.89 \\
\hline
\end{tabular}




\section{Table 6: Summary Statistics for Banking Variables}

This table shows summary statistics for variables related to the bank levy used in subsequent regressions and other bank-specific variables, such as banks' total assets (billion $€$ ) and the CAMEL variables (i.e., Tier 1 capital ratio, NPL ratio, cost-to-income ratio, RoA, liquidity ratio) and market share. Descriptive statistics are based on the full sample and the subsample of banks reporting within the scope of the MFI interest rate statistics, over the period 2003-2011. The dummy variable Bank levy (0/1) is equal to 1 if in 2011 the bank had contributionrelevant liabilities higher than $€ 300$ million. The dummy variable Bank levy high $_{(0 / 1)}$ is equal to 1 if in 2011 the bank had contribution-relevant liabilities of more than $€ 10$ billion. Total assets denote bank assets in billion $€$. Tier 1 capital ratio is the fraction of Tier 1 capital relative to risk-weighted assets. NPL ratio describes the fraction of write-offs on a bank's loan portfolio relative to the size of the total loan portfolio. Cost-to-income ratio relates the cost (excluding extraordinary items) to the revenues (excluding extraordinary items). Ro $\mathrm{A}$ measures the earnings before tax relative to total assets. Liquidity ratio measures the fraction of the liquidity held by a bank relative to total assets. Market share is defined as the total assets of bank $i$ relative to the sum of total assets of all banks in the sample at time $t$. For more details, see the description in the Data Appendix.

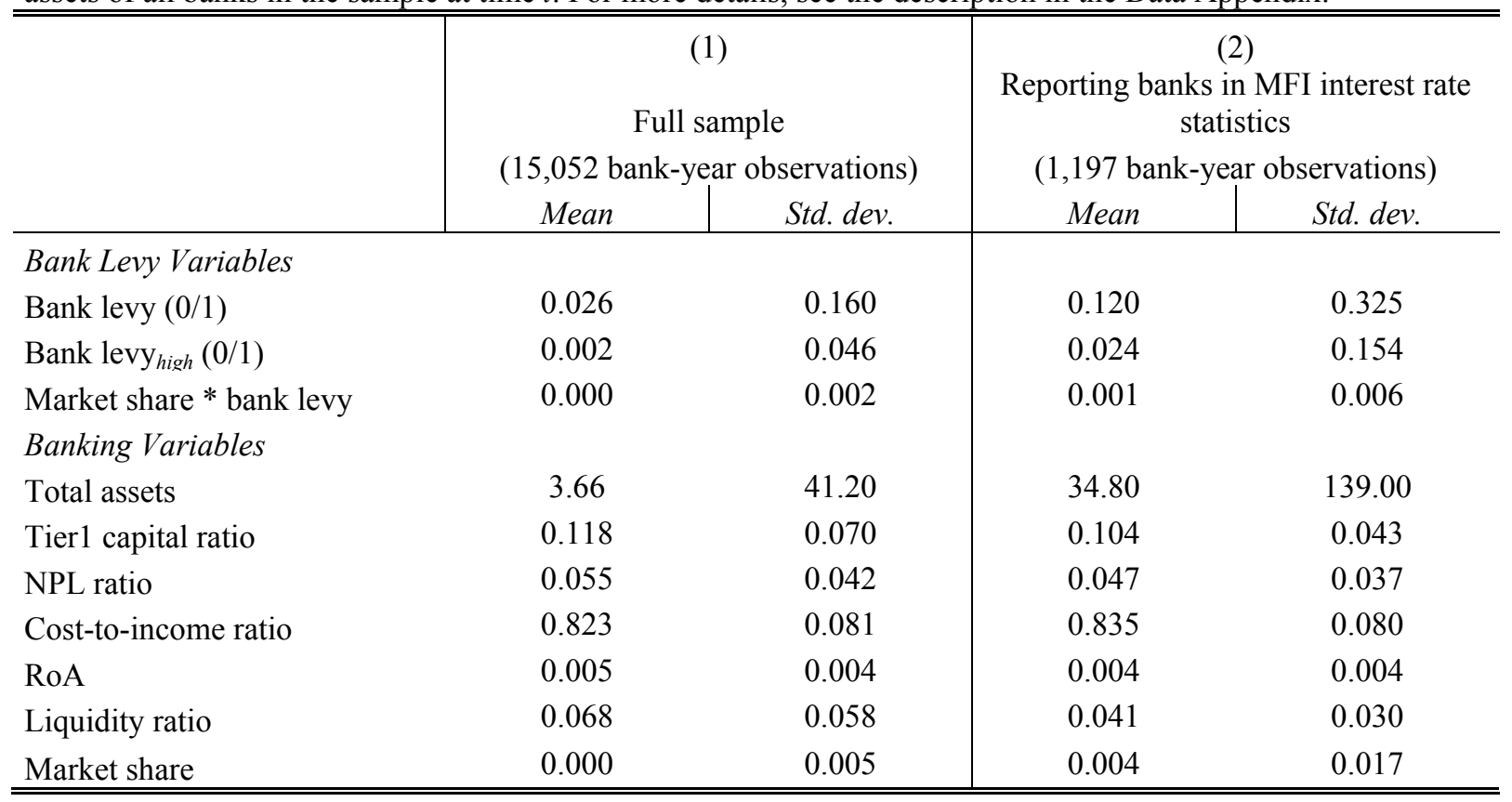




\section{Table 7: Baseline Regression Results: Loan Volumes}

This table shows the regression results of the estimation specified in Equation (1). The estimations are based on the sample of banks that report to the MFI interest rate statistics and cover 2003-2011. The dependent variable is either newly granted loans ("New Loans") or the volume of existing loans ("Loans"). The effect of the bank levy ("Bank levy (0/1)") is the coefficient on the dummy "Charged Bank*After2010," equal to 1 in the year 2011 if the bank had contribution-relevant liabilities higher than $€ 300$ million. Total assets are expressed in million $€$. The independent variables comprise the CAMEL variables, as defined in Section 3.3, included with a lag. The merger dummy is equal to 1 if a merger took place in a given year and 0 otherwise. Time and bank fixed effects are included but not reported. The standard errors are robust to heteroscedasticity. *, **, *** indicate significance at the $10 \%, 5 \%, 1 \%$ level, respectively.

\begin{tabular}{|c|c|c|c|c|}
\hline & $\begin{array}{c}(1) \\
\text { New Loans (log) }\end{array}$ & $\begin{array}{c}(2) \\
\text { Loans }(\log ) \\
\end{array}$ & $\begin{array}{c}\text { (3) } \\
\text { Loans / Assets }\end{array}$ & $\begin{array}{c}(4) \\
\text { Loans (YoY change) }\end{array}$ \\
\hline Bank levy $(0,1)$ & $\begin{array}{c}0.252 \\
(0.198)\end{array}$ & $\begin{array}{l}-0.008 \\
(0.033)\end{array}$ & $\begin{array}{c}0.015 \\
(0.020)\end{array}$ & $\begin{array}{l}-0.008 \\
(0.016)\end{array}$ \\
\hline Log total assets & $\begin{array}{l}1.403 * \\
(0.751)\end{array}$ & $\begin{array}{l}1.161^{* * *} \\
(0.238)\end{array}$ & $\begin{array}{c}0.123 \\
(0.097)\end{array}$ & $\begin{array}{l}-0.171 \\
(0.108)\end{array}$ \\
\hline Log total assets ${ }^{2}$ & $\begin{array}{l}-0.055 \\
(0.034)\end{array}$ & $\begin{array}{l}-0.024 * \\
(0.014)\end{array}$ & $\begin{array}{l}-0.009 \\
(0.005)\end{array}$ & $\begin{array}{l}-0.001 \\
(0.005)\end{array}$ \\
\hline Tier1 capital ratio & $\begin{array}{l}-0.452 \\
(1.470)\end{array}$ & $\begin{array}{c}0.292 \\
(0.382)\end{array}$ & $\begin{array}{l}-0.104 \\
(0.239)\end{array}$ & $\begin{array}{c}0.198 \\
(0.288)\end{array}$ \\
\hline NPL ratio & $\begin{array}{l}-1.415 \\
(1.204)\end{array}$ & $\begin{array}{l}-0.602 * * \\
(0.260)\end{array}$ & $\begin{array}{l}-0.080 \\
(0.150)\end{array}$ & $\begin{array}{c}-0.760 * * * \\
(0.173)\end{array}$ \\
\hline Cost-to-income ratio & $\begin{array}{c}0.187 \\
(0.516)\end{array}$ & $\begin{array}{c}-0.365^{* * *} \\
(0.134)\end{array}$ & $\begin{array}{l}-0.118 * * \\
(0.058)\end{array}$ & $\begin{array}{l}-0.141 \\
(0.106)\end{array}$ \\
\hline RoA & $\begin{array}{c}8.877 \\
(7.416)\end{array}$ & $\begin{array}{l}2.652 * \\
(1.545)\end{array}$ & $\begin{array}{c}0.051 \\
(0.752)\end{array}$ & $\begin{array}{l}2.109 * * \\
(1.056)\end{array}$ \\
\hline Liquidity ratio & $\begin{array}{l}-0.913 \\
(0.906)\end{array}$ & $\begin{array}{l}0.847 * * \\
(0.335)\end{array}$ & $\begin{array}{c}0.521 * * * \\
(0.154)\end{array}$ & $\begin{array}{c}-0.543 * * * \\
(0.162)\end{array}$ \\
\hline Merger dummy & $\begin{array}{c}0.120 \\
(0.082)\end{array}$ & $\begin{array}{c}0.123 * * * \\
(0.023)\end{array}$ & $\begin{array}{l}-0.005 \\
(0.012)\end{array}$ & $\begin{array}{c}0.146^{* * *} \\
(0.023)\end{array}$ \\
\hline Constant & $\begin{array}{c}5.292 \\
(4.226)\end{array}$ & $\begin{array}{c}7.293 * * * \\
(1.059)\end{array}$ & $\begin{array}{c}0.396 \\
(0.472)\end{array}$ & $\begin{array}{c}1.745 * * * \\
(0.607)\end{array}$ \\
\hline Observations & 1,176 & 1,176 & 1,176 & 1,176 \\
\hline $\mathrm{R}^{2}$ & 0.274 & 0.542 & 0.091 & 0.249 \\
\hline Number of banks & 163 & 163 & 163 & 163 \\
\hline
\end{tabular}




\section{Table 8: Baseline Regression Results: Loan Rates}

This table shows the regression results of the estimation in Equation (1). The estimations are based on the sample of banks that report to the MFI interest rate statistics and cover 2003-2011. The dependent variable is the interest rate charged on newly granted loans for different maturities: short-term: < 1 year; medium-term: $\geq 1$ year $\&<5$ years; long-term: $\geq 5$ years $\&<10$ years. The effect of the bank levy ("Bank levy (0/1)") is the coefficient on the dummy "Charged Bank * After2010," which is equal to 1 in 2011 if the bank had contribution-relevant liabilities higher than $€ 300$ million. Total assets are expressed in million $€$. The independent variables comprise the CAMEL variables, defined in Section 3.3, included with a lag. The merger dummy is equal to 1 if a merger took place in a given year and 0 otherwise. Time and bank fixed effects are included but not reported. The standard errors are robust to heteroscedasticity. $*, * *, * * *$ indicate significance at the $10 \%, 5 \%, 1 \%$ levels, respectively.

\begin{tabular}{|c|c|c|c|c|}
\hline & $\begin{array}{c}\text { (1) } \\
\text { All maturities }\end{array}$ & $\begin{array}{c}(2) \\
\text { Short-term }\end{array}$ & $\begin{array}{c}(3) \\
\text { Medium-term }\end{array}$ & $\begin{array}{c}\text { (4) } \\
\text { Long-term }\end{array}$ \\
\hline \multirow[t]{2}{*}{ Bank levy $(0,1)$} & -0.084 & 0.018 & 0.055 & -0.108 \\
\hline & $(0.185)$ & $(0.304)$ & $(0.277)$ & $(0.231)$ \\
\hline \multirow[t]{2}{*}{ Log total assets } & $-4.181 * * *$ & $-5.264 * * *$ & -0.127 & -0.496 \\
\hline & $(0.866)$ & $(1.405)$ & $(1.428)$ & $(1.412)$ \\
\hline \multirow[t]{2}{*}{ Log total assets ${ }^{2}$} & $0.233 * * *$ & $0.287 * * *$ & -0.001 & 0.030 \\
\hline & $(0.042)$ & $(0.066)$ & $(0.075)$ & $(0.076)$ \\
\hline \multirow[t]{2}{*}{ Tier1 capital ratio } & 1.608 & -2.706 & 2.652 & 2.158 \\
\hline & $(2.048)$ & $(4.242)$ & (2.174) & $(1.363)$ \\
\hline \multirow[t]{2}{*}{ NPL ratio } & 0.402 & -0.193 & 0.444 & 0.560 \\
\hline & $(1.649)$ & $(2.562)$ & $(1.592)$ & $(1.393)$ \\
\hline \multirow[t]{2}{*}{ Cost-to-income ratio } & 0.549 & 0.398 & 0.560 & -0.451 \\
\hline & $(0.871)$ & $(0.954)$ & $(0.757)$ & $(1.141)$ \\
\hline \multirow[t]{2}{*}{ RoA } & -8.131 & $-23.671 *$ & 3.687 & -10.719 \\
\hline & $(13.242)$ & (13.968) & $(12.017)$ & (12.916) \\
\hline \multirow[t]{2}{*}{ Liquidity ratio } & 1.099 & 1.818 & 0.540 & 1.610 \\
\hline & $(0.823)$ & $(1.651)$ & $(1.165)$ & $(1.399)$ \\
\hline \multirow[t]{2}{*}{ Merger dummy } & 0.009 & -0.013 & 0.043 & 0.016 \\
\hline & $(0.089)$ & $(0.124)$ & $(0.114)$ & $(0.085)$ \\
\hline \multirow[t]{2}{*}{ Constant } & $21.045^{* * *}$ & $28.197 * * *$ & 5.129 & 6.903 \\
\hline & $(4.737)$ & $(7.691)$ & $(6.944)$ & $(7.160)$ \\
\hline Observations & 1,167 & 1,134 & 1,125 & 1,122 \\
\hline $\mathrm{R}^{2}$ & 0.632 & 0.598 & 0.302 & 0.411 \\
\hline Number of banks & 161 & 153 & 158 & 159 \\
\hline
\end{tabular}




\section{Table 9: Baseline Regression Results: Deposit Rates}

This table shows the regression results of the estimation specified in Equation (1). The estimations are based on the sample of banks that report to the MFI interest rate statistics and cover 2003-2011. The dependent variable is the interest rate paid for newly received deposits for different maturities: overnight, short-term: $<1$ year; medium-term: $\geq 1$ year. The effect of the bank levy ("Bank levy (0/1)") is the coefficient on the dummy "Charged Bank* After2010," which is equal to 1 in 2011 if the bank had contribution-relevant liabilities higher than $€ 300$ million. Total assets are expressed in million $€$. The independent variables comprise the CAMEL variables, as defined in Section 3.3, included with a lag. The merger dummy is equal to 1 if a merger took place in a given year and 0 otherwise. Time and bank fixed effects are included but not reported. The standard errors are robust to heteroscedasticity. ${ }^{*}, * * * * *$ indicate significance at the $10 \%, 5 \%, 1 \%$ levels, respectively.

\begin{tabular}{|c|c|c|c|c|}
\hline Variable & $\begin{array}{c}\text { (1) } \\
\text { All maturities }\end{array}$ & $\begin{array}{c}(2) \\
\text { Overnight }\end{array}$ & $\begin{array}{c}(3) \\
\text { Short-term }\end{array}$ & $\begin{array}{c}(4) \\
\text { Medium-term } \\
\end{array}$ \\
\hline \multirow[t]{2}{*}{ Bank levy $(0,1)$} & -0.007 & -0.037 & -0.002 & -0.125 \\
\hline & $(0.130)$ & $(0.083)$ & $(0.135)$ & $(0.106)$ \\
\hline \multirow[t]{2}{*}{ Log total assets } & $0.959 * *$ & 0.416 & $0.971 * * *$ & 0.165 \\
\hline & $(0.379)$ & $(0.442)$ & $(0.345)$ & $(0.561)$ \\
\hline \multirow[t]{2}{*}{ Log total assets ${ }^{2}$} & $-0.055 * * *$ & -0.030 & $-0.048 * * *$ & -0.001 \\
\hline & $(0.018)$ & $(0.022)$ & $(0.017)$ & $(0.029)$ \\
\hline \multirow[t]{2}{*}{ Tier1 capital ratio } & $2.423 *$ & $2.566^{* *}$ & 1.275 & 1.937 \\
\hline & $(1.260)$ & $(1.030)$ & $(1.036)$ & $(1.537)$ \\
\hline \multirow[t]{2}{*}{ NPL ratio } & $-1.442 * *$ & 1.360 & $-1.314 * *$ & -0.926 \\
\hline & $(0.659)$ & $(2.150)$ & $(0.554)$ & $(0.931)$ \\
\hline \multirow[t]{2}{*}{ Cost-to-income ratio } & 0.453 & 0.273 & 0.274 & -0.009 \\
\hline & $(0.349)$ & $(0.405)$ & $(0.259)$ & $(0.375)$ \\
\hline \multirow[t]{2}{*}{ RoA } & $9.932 * *$ & 4.439 & -0.559 & 2.209 \\
\hline & $(4.179)$ & $(6.404)$ & $(4.800)$ & $(8.032)$ \\
\hline \multirow[t]{2}{*}{ Liquidity ratio } & $-1.040 *$ & -0.852 & -0.205 & $-1.209 *$ \\
\hline & $(0.609)$ & $(0.632)$ & $(0.507)$ & $(0.617)$ \\
\hline \multirow[t]{2}{*}{ Merger dummy } & 0.003 & $-0.069 *$ & 0.023 & -0.015 \\
\hline & $(0.056)$ & $(0.036)$ & $(0.051)$ & $(0.047)$ \\
\hline \multirow[t]{2}{*}{ Constant } & -3.343 & -1.206 & $-4.187 * *$ & 0.496 \\
\hline & $(2.174)$ & $(2.306)$ & $(1.853)$ & $(2.901)$ \\
\hline Observations & 1,143 & 1,151 & 1,105 & 1,061 \\
\hline $\mathrm{R}^{2}$ & 0.876 & 0.639 & 0.916 & 0.750 \\
\hline Number of banks & 158 & 154 & 146 & 156 \\
\hline
\end{tabular}




\section{Table 10: Regression Results: Effect of Market Share on Loan Volumes}

This table shows the regression results of the estimation in Equation (2). The estimations are based on the sample of banks that report to the MFI interest rate statistics and cover 2003-2011. The dependent variable is either newly granted loans ("New Loans") or the volume of existing loans ("Loans"). The effect of the bank levy ("Bank levy (0/1)") is the coefficient on the dummy "Charged Bank* After2010," which is equal to 1 in 2011 if the bank had contribution-relevant liabilities higher than $€ 300$ million. In addition, we include an interaction term that is not equal to 0 if the bank is subject to the bank levy in 2011 and that increases with a bank's market share. Market share is the bank's share in total assets of all banks included in the data set. Total assets are expressed in million $€$. The independent variables comprise the CAMEL variables, as defined in Section 3.3, included with a lag. The merger dummy is equal to 1 if a merger took place in a given year and 0 otherwise. Time and bank fixed effects are included but not reported. The standard errors are robust to heteroscedasticity. *, $* *, * * *$ indicate significance at the $10 \%, 5 \%, 1 \%$ levels, respectively.

\begin{tabular}{|c|c|c|c|c|}
\hline & $\begin{array}{c}(1) \\
\text { New Loans }(\log ) \\
\end{array}$ & $\begin{array}{c}(2) \\
\text { Loans (log) } \\
\end{array}$ & $\begin{array}{c}\text { (3) } \\
\text { Loans / Assets }\end{array}$ & $\begin{array}{c}\text { (4) } \\
\text { Loans (YoY change) }\end{array}$ \\
\hline Bank levy $(0,1)$ & $\begin{array}{c}0.262 \\
(0.199)\end{array}$ & $\begin{array}{c}0.004 \\
(0.033)\end{array}$ & $\begin{array}{c}0.020 \\
(0.021)\end{array}$ & $\begin{array}{l}-0.009 \\
(0.016)\end{array}$ \\
\hline Market share * bank levy & $\begin{array}{l}-2.538 \\
(2.396)\end{array}$ & $\begin{array}{l}-3.008 * \\
(1.546)\end{array}$ & $\begin{array}{c}-1.321 * * \\
(0.586)\end{array}$ & $\begin{array}{c}0.268 \\
(0.512)\end{array}$ \\
\hline Log total assets & $\begin{array}{c}1.298 \\
(0.785)\end{array}$ & $\begin{array}{l}1.037 * * * \\
(0.269)\end{array}$ & $\begin{array}{c}0.068 \\
(0.105)\end{array}$ & $\begin{array}{l}-0.160 \\
(0.109)\end{array}$ \\
\hline Log total assets ${ }^{2}$ & $\begin{array}{l}-0.049 \\
(0.036)\end{array}$ & $\begin{array}{l}-0.017 \\
(0.016)\end{array}$ & $\begin{array}{l}-0.006 \\
(0.006)\end{array}$ & $\begin{array}{l}-0.002 \\
(0.005)\end{array}$ \\
\hline Tier1 capital ratio & $\begin{array}{l}-0.418 \\
(1.476)\end{array}$ & $\begin{array}{c}0.333 \\
(0.377)\end{array}$ & $\begin{array}{l}-0.086 \\
(0.237)\end{array}$ & $\begin{array}{c}0.195 \\
(0.290)\end{array}$ \\
\hline NPL ratio & $\begin{array}{l}-1.346 \\
(1.212)\end{array}$ & $\begin{array}{c}-0.520 * * \\
(0.257)\end{array}$ & $\begin{array}{l}-0.043 \\
(0.151)\end{array}$ & $\begin{array}{c}-0.768 * * * \\
(0.175)\end{array}$ \\
\hline Cost-to-income ratio & $\begin{array}{c}0.234 \\
(0.526)\end{array}$ & $\begin{array}{c}-0.309 * * \\
(0.138)\end{array}$ & $\begin{array}{l}-0.093 \\
(0.059)\end{array}$ & $\begin{array}{l}-0.146 \\
(0.105)\end{array}$ \\
\hline RoA & $\begin{array}{c}9.190 \\
(7.451)\end{array}$ & $\begin{array}{l}3.023^{*} \\
(1.575)\end{array}$ & $\begin{array}{c}0.214 \\
(0.768)\end{array}$ & $\begin{array}{c}2.076^{* *} \\
(1.043)\end{array}$ \\
\hline Liquidity ratio & $\begin{array}{l}-0.986 \\
(0.931)\end{array}$ & $\begin{array}{l}0.761 * * \\
(0.346)\end{array}$ & $\begin{array}{c}0.483 * * * \\
(0.157)\end{array}$ & $\begin{array}{c}-0.535^{* * *} \\
(0.159)\end{array}$ \\
\hline Merger dummy & $\begin{array}{c}0.119 \\
(0.082)\end{array}$ & $\begin{array}{c}0.121 * * * \\
(0.023)\end{array}$ & $\begin{array}{l}-0.006 \\
(0.012)\end{array}$ & $\begin{array}{c}0.146 * * * \\
(0.023)\end{array}$ \\
\hline Constant & $\begin{array}{r}5.706 \\
(4.328)\end{array}$ & $\begin{array}{c}7.784 * * * \\
(1.172)\end{array}$ & $\begin{array}{c}0.612 \\
(0.495)\end{array}$ & $\begin{array}{c}1.701 * * * \\
(0.606)\end{array}$ \\
\hline Observations & 1,176 & 1,176 & 1,176 & 1,176 \\
\hline $\mathrm{R}^{2}$ & 0.274 & 0.552 & 0.107 & 0.249 \\
\hline Number of banks & 163 & 163 & 163 & 163 \\
\hline
\end{tabular}




\section{Table 11: Regression Results: Effect of Market Share on Loan Rates}

This table shows the regression results of the estimation specified in Equation (2). The estimations are based on the sample of banks that report to the MFI interest rate statistics and cover 2003-2011. The dependent variable is the interest rate charged on newly granted loans for different maturities: short-term: $<1$ year; medium-term: $\geq 1$ year $\&<5$ years; long-term: $\geq 5$ years $\&<10$ years. The effect of the bank levy ("Bank levy (0/1)") is the coefficient on the dummy "Charged Bank* After2010," which is equal to 1 in 2011 if the bank had contributionrelevant liabilities higher than $€ 300$ million. In addition, we include an interaction term that is not equal to 0 if the bank is subject to the bank levy in 2011 and that increases with a bank's market share. Market share is defined as the bank's share in total assets of all banks included in the data set. Total assets are expressed in million $€$. The independent variables comprise the CAMEL variables, as defined in Section 3.3, included with a lag. The merger dummy is equal to 1 if a merger took place in a given year and 0 otherwise. Time and bank fixed effects are included but not reported. The standard errors are robust to heteroscedasticity. $*, * *, * * *$ indicate significance at the $10 \%, 5 \%, 1 \%$ levels, respectively.

\begin{tabular}{|c|c|c|c|c|}
\hline Variable & $\begin{array}{c}(1) \\
\text { All maturities } \\
\end{array}$ & $\begin{array}{c}(2) \\
\text { Short-term }\end{array}$ & $\begin{array}{c}(3) \\
\text { Medium-term }\end{array}$ & $\begin{array}{c}\text { (4) } \\
\text { Long-term }\end{array}$ \\
\hline Bank levy $(0,1)$ & $\begin{array}{l}-0.101 \\
(0.185)\end{array}$ & $\begin{array}{c}0.002 \\
(0.302)\end{array}$ & $\begin{array}{c}0.060 \\
(0.278)\end{array}$ & $\begin{array}{c}-0.112 \\
(0.230)\end{array}$ \\
\hline Market share * bank levy & $\begin{array}{c}4.493 * * \\
(1.835)\end{array}$ & $\begin{array}{l}4.791^{*} \\
(2.464)\end{array}$ & $\begin{array}{l}-1.328 \\
(2.330)\end{array}$ & $\begin{array}{c}0.952 \\
(1.839)\end{array}$ \\
\hline Log total assets & $\begin{array}{c}-3.996 * * * \\
(0.873)\end{array}$ & $\begin{array}{c}-5.058 * * * \\
(1.443)\end{array}$ & $\begin{array}{l}-0.182 \\
(1.389)\end{array}$ & $\begin{array}{l}-0.457 \\
(1.430)\end{array}$ \\
\hline Log total assets ${ }^{2}$ & $\begin{array}{c}0.223 * * * \\
(0.042)\end{array}$ & $\begin{array}{c}0.276 * * * \\
(0.068)\end{array}$ & $\begin{array}{c}0.002 \\
(0.073)\end{array}$ & $\begin{array}{c}0.028 \\
(0.077)\end{array}$ \\
\hline Tier1 capital ratio & $\begin{array}{c}1.546 \\
(2.056)\end{array}$ & $\begin{array}{l}-2.789 \\
(4.249)\end{array}$ & $\begin{array}{c}2.674 \\
(2.179)\end{array}$ & $\begin{array}{c}2.143 \\
(1.369)\end{array}$ \\
\hline NPL ratio & $\begin{array}{c}0.278 \\
(1.678)\end{array}$ & $\begin{array}{l}-0.326 \\
(2.601)\end{array}$ & $\begin{array}{c}0.482 \\
(1.600)\end{array}$ & $\begin{array}{c}0.531 \\
(1.423)\end{array}$ \\
\hline Cost-to-income ratio & $\begin{array}{c}0.465 \\
(0.886)\end{array}$ & $\begin{array}{c}0.301 \\
(0.961)\end{array}$ & $\begin{array}{c}0.588 \\
(0.771)\end{array}$ & $\begin{array}{l}-0.472 \\
(1.167)\end{array}$ \\
\hline RoA & $\begin{array}{c}-8.697 \\
(13.243)\end{array}$ & $\begin{array}{l}-24.299 * \\
(13.966)\end{array}$ & $\begin{array}{c}3.856 \\
(12.042)\end{array}$ & $\begin{array}{l}-10.838 \\
(13.060)\end{array}$ \\
\hline Liquidity ratio & $\begin{array}{c}1.227 \\
(0.837)\end{array}$ & $\begin{array}{c}1.969 \\
(1.668)\end{array}$ & $\begin{array}{c}0.498 \\
(1.162)\end{array}$ & $\begin{array}{c}1.641 \\
(1.431)\end{array}$ \\
\hline Merger dummy & $\begin{array}{c}0.011 \\
(0.090)\end{array}$ & $\begin{array}{l}-0.010 \\
(0.125)\end{array}$ & $\begin{array}{c}0.042 \\
(0.114)\end{array}$ & $\begin{array}{c}0.016 \\
(0.085)\end{array}$ \\
\hline Constant & $\begin{array}{c}20.315^{* * *} \\
(4.747)\end{array}$ & $\begin{array}{c}27.382 * * * \\
(7.814)\end{array}$ & $\begin{array}{c}5.338 \\
(6.810)\end{array}$ & $\begin{array}{c}6.750 \\
(7.169)\end{array}$ \\
\hline Observations & 1,167 & 1,134 & 1,125 & 1,122 \\
\hline $\mathrm{R}^{2}$ & 0.632 & 0.598 & 0.302 & 0.411 \\
\hline Number of banks & 161 & 153 & 158 & 159 \\
\hline
\end{tabular}




\section{Table 12: Regression Results: Effect of Market Share on Deposit Rates}

This table shows the regression results of the estimation specified in Equation (2). The estimations are based on the sample of banks that report to the MFI interest rate statistics and cover 2003-2011. The dependent variable is the interest rate paid for newly received deposits for different maturities: overnight, short-term: $<1$ year; medium-term: $\geq 1$ year. The effect of the bank levy ("Bank levy (0/1)") is the coefficient on the dummy "Charged Bank*After2010," which is equal to 1 in 2011 if the bank had contribution-relevant liabilities higher than $€ 300$ million. In addition, we include an interaction term that is not equal to 0 if the bank is subject to the bank levy in 2011 and that increases with a bank's market share. Market share is defined as the bank's share in total assets of all banks included in the data set. Total assets are expressed in million $€$. The independent variables comprise the CAMEL variables, as defined in Section 3.3, included with a lag. The merger dummy is equal to 1 if a merger took place in a given year and 0 otherwise. Time and bank fixed effects are included but not reported. The standard errors are robust to heteroscedasticity. *,**,*** indicate significance at the $10 \%, 5 \%$, $1 \%$ levels, respectively.

\begin{tabular}{|c|c|c|c|c|}
\hline & $\begin{array}{c}(1) \\
\text { All maturities }\end{array}$ & $\begin{array}{c}(2) \\
\text { Overnight }\end{array}$ & $\begin{array}{c}(3) \\
\text { Short-term }\end{array}$ & $\begin{array}{c}\text { (4) } \\
\text { Medium-term }\end{array}$ \\
\hline Bank levy $(0,1)$ & $\begin{array}{c}0.007 \\
(0.130)\end{array}$ & $\begin{array}{l}-0.023 \\
(0.083)\end{array}$ & $\begin{array}{c}0.016 \\
(0.137)\end{array}$ & $\begin{array}{l}-0.110 \\
(0.105)\end{array}$ \\
\hline Market share * bank levy & $\begin{array}{c}-3.658 * * * \\
(1.368)\end{array}$ & $\begin{array}{l}-3.701 * \\
(2.078)\end{array}$ & $\begin{array}{c}-4.396 * * * \\
(1.368)\end{array}$ & $\begin{array}{l}-4.190 \\
(3.566)\end{array}$ \\
\hline Log total assets & $\begin{array}{c}0.804 * * \\
(0.374)\end{array}$ & $\begin{array}{c}0.264 \\
(0.459)\end{array}$ & $\begin{array}{c}0.786 * * \\
(0.341)\end{array}$ & $\begin{array}{l}-0.010 \\
(0.607)\end{array}$ \\
\hline Log total assets ${ }^{2}$ & $\begin{array}{c}-0.046^{* * *} \\
(0.018)\end{array}$ & $\begin{array}{l}-0.021 \\
(0.023)\end{array}$ & $\begin{array}{c}-0.038 * * \\
(0.017)\end{array}$ & $\begin{array}{c}0.009 \\
(0.032)\end{array}$ \\
\hline Tier1 capital ratio & $\begin{array}{l}2.478^{*} \\
(1.259)\end{array}$ & $\begin{array}{c}2.615 * * \\
(1.048)\end{array}$ & $\begin{array}{c}1.345 \\
(1.026)\end{array}$ & $\begin{array}{c}1.994 \\
(1.515)\end{array}$ \\
\hline NPL ratio & $\begin{array}{c}-1.327 * * \\
(0.662)\end{array}$ & $\begin{array}{c}1.463 \\
(2.167)\end{array}$ & $\begin{array}{c}-1.174 * * \\
(0.551)\end{array}$ & $\begin{array}{l}-0.808 \\
(0.934)\end{array}$ \\
\hline Cost-to-income ratio & $\begin{array}{c}0.528 \\
(0.351)\end{array}$ & $\begin{array}{c}0.345 \\
(0.418)\end{array}$ & $\begin{array}{c}0.369 \\
(0.254)\end{array}$ & $\begin{array}{c}0.081 \\
(0.379)\end{array}$ \\
\hline RoA & $\begin{array}{c}10.452 * * \\
(4.239)\end{array}$ & $\begin{array}{c}4.925 \\
(6.412)\end{array}$ & $\begin{array}{c}0.122 \\
(4.748)\end{array}$ & $\begin{array}{c}2.812 \\
(8.104)\end{array}$ \\
\hline Liquidity ratio & $\begin{array}{l}-1.147 * \\
(0.629)\end{array}$ & $\begin{array}{l}-0.959 \\
(0.656)\end{array}$ & $\begin{array}{l}-0.334 \\
(0.515)\end{array}$ & $\begin{array}{c}-1.333 * * \\
(0.624)\end{array}$ \\
\hline Merger dummy & $\begin{array}{c}0.001 \\
(0.056)\end{array}$ & $\begin{array}{l}-0.071 * \\
(0.037)\end{array}$ & $\begin{array}{c}0.021 \\
(0.052)\end{array}$ & $\begin{array}{l}-0.018 \\
(0.047)\end{array}$ \\
\hline Constant & $\begin{array}{l}-2.730 \\
(2.143)\end{array}$ & $\begin{array}{l}-0.611 \\
(2.335)\end{array}$ & $\begin{array}{l}-3.464^{*} \\
(1.832)\end{array}$ & $\begin{array}{c}1.189 \\
(3.041)\end{array}$ \\
\hline Observations & 1,143 & 1,151 & 1,105 & 1,061 \\
\hline $\mathrm{R}^{2}$ & 0.876 & 0.641 & 0.917 & 0.751 \\
\hline Number of banks & 158 & 154 & 146 & 156 \\
\hline
\end{tabular}




\section{Table 13: Regression Results: Size Effect of Bank Levy on Loan Volumes}

This table shows the regression results of the estimation specified in Equation (3). The estimations are based on the sample of banks that report to the MFI interest rate statistics and cover 2003-2011. The sample is restricted to MFI banks that had more than $€ 300$ million of contribution-relevant liabilities. The dependent variable is either newly granted loans ("New Loans") or the volume of existing loans ("Loans"). The effect of the bank levy

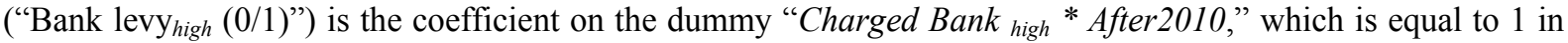
2011 if the bank had contribution-relevant liabilities higher than $€ 10$ billion and 0 if the bank's contributionrelevant liabilities were greater than $€ 300$ million but less than or equal to $€ 10$ billion. Total assets are expressed in million $€$. The independent variables comprise the CAMEL variables, as defined in Section 3.3, included with a lag. The merger dummy is equal to 1 if a merger took place in a given year and 0 otherwise. Time and bank fixed effects are included but not reported. The standard errors are robust to heteroscedasticity. *, **, *** indicate significance at the $10 \%, 5 \%, 1 \%$ levels, respectively.

\begin{tabular}{|c|c|c|c|c|}
\hline & $\begin{array}{c}(1) \\
\text { New Loans }(\log ) \\
\end{array}$ & $\begin{array}{c}(2) \\
\text { Loans }(\log ) \\
\end{array}$ & $\begin{array}{c}\text { (3) } \\
\text { Loans / Assets }\end{array}$ & $\begin{array}{c}(4) \\
\text { Loans (YoY change) }\end{array}$ \\
\hline $\operatorname{Bank}_{\text {levy }}$ high $(0,1)$ & $\begin{array}{l}-0.189 \\
(0.163)\end{array}$ & $\begin{array}{c}-0.130 * * * \\
(0.046)\end{array}$ & $\begin{array}{c}-0.046^{* *} \\
(0.020)\end{array}$ & $\begin{array}{l}-0.034 \\
(0.021)\end{array}$ \\
\hline Log total assets & $\begin{array}{c}0.448 \\
(0.854)\end{array}$ & $\begin{array}{c}1.060 * * * \\
(0.299)\end{array}$ & $\begin{array}{c}0.043 \\
(0.118)\end{array}$ & $\begin{array}{l}-0.238 * \\
(0.125)\end{array}$ \\
\hline Log total assets ${ }^{2}$ & $\begin{array}{l}-0.016 \\
(0.038)\end{array}$ & $\begin{array}{l}-0.018 \\
(0.017)\end{array}$ & $\begin{array}{l}-0.005 \\
(0.006)\end{array}$ & $\begin{array}{c}0.002 \\
(0.006)\end{array}$ \\
\hline Tier1 capital ratio & $\begin{array}{c}0.014 \\
(1.541)\end{array}$ & $\begin{array}{c}0.345 \\
(0.421)\end{array}$ & $\begin{array}{l}-0.058 \\
(0.260)\end{array}$ & $\begin{array}{c}0.238 \\
(0.318)\end{array}$ \\
\hline NPL ratio & $\begin{array}{l}-1.435 \\
(1.359)\end{array}$ & $\begin{array}{l}-0.472 * \\
(0.277)\end{array}$ & $\begin{array}{l}-0.102 \\
(0.166)\end{array}$ & $\begin{array}{c}-0.736^{* * *} \\
(0.197)\end{array}$ \\
\hline Cost-to-income ratio & $\begin{array}{c}0.359 \\
(0.558)\end{array}$ & $\begin{array}{c}-0.374 * * \\
(0.152)\end{array}$ & $\begin{array}{c}-0.130 * * \\
(0.064)\end{array}$ & $\begin{array}{l}-0.119 \\
(0.120)\end{array}$ \\
\hline RoA & $\begin{array}{c}6.509 \\
(8.128)\end{array}$ & $\begin{array}{l}3.138 * * \\
(1.577)\end{array}$ & $\begin{array}{c}0.078 \\
(0.804)\end{array}$ & $\begin{array}{l}2.383 * * \\
(1.086)\end{array}$ \\
\hline Liquidity ratio & $\begin{array}{l}-1.856 \\
(1.365)\end{array}$ & $\begin{array}{c}0.510 \\
(0.373)\end{array}$ & $\begin{array}{c}0.421 * * * \\
(0.148)\end{array}$ & $\begin{array}{l}-0.450 * \\
(0.232)\end{array}$ \\
\hline Merger dummy & $\begin{array}{c}0.100 \\
(0.079)\end{array}$ & $\begin{array}{c}0.114 * * * \\
(0.024)\end{array}$ & $\begin{array}{c}-0.018 * * \\
(0.008)\end{array}$ & $\begin{array}{c}0.136 * * * \\
(0.024)\end{array}$ \\
\hline Constant & $\begin{array}{c}10.693 * * \\
(4.742)\end{array}$ & $\begin{array}{c}7.772 * * * \\
(1.337)\end{array}$ & $\begin{array}{r}0.832 \\
(0.568)\end{array}$ & $\begin{array}{c}2.065^{* * *} \\
(0.709)\end{array}$ \\
\hline Observations & 1,057 & 1,057 & 1,057 & 1,057 \\
\hline $\mathrm{R}^{2}$ & 0.283 & 0.558 & 0.100 & 0.251 \\
\hline Number of banks & 146 & 146 & 146 & 146 \\
\hline
\end{tabular}




\section{Table 14: Regression Results: Size Effect of Bank Levy on Loan Rates}

This table shows the regression results of the estimation specified in Equation (3). The estimations are based on the sample of banks that report to the MFI interest rate statistics and cover 2003-2011. The sample is restricted to MFI banks that had more than $€ 300$ million of contribution-relevant liabilities. The dependent variable is the interest rate charged on newly granted loans for different maturities: short-term: $<1$ year; medium-term: $\geq 1$ year $\&<5$ years; long-term: $\geq 5$ years $\&<10$ years. The effect of the bank levy ("Bank levy ${ }_{\text {high }}(0 / 1)$ ") is the coefficient on the dummy "Charged Bank high * After2010," which is equal to 1 in 2011 if the bank had contribution-relevant liabilities higher than $€ 10$ billion and 0 if its contribution-relevant liabilities were greater than $€ 300$ million but less than or equal to $€ 10$ billion. Total assets are expressed in million $€$. The independent variables comprise the CAMEL variables, as defined in Section 3.3, included with a lag. The merger dummy is equal to 1 if a merger took place in a given year and 0 otherwise. Time and bank fixed effects are included but not reported. The standard errors are robust to heteroscedasticity. $*, * * * * *$ indicate significance at the $10 \%, 5 \%$, $1 \%$ levels, respectively.

\begin{tabular}{|c|c|c|c|c|}
\hline & $\begin{array}{c}\text { (1) } \\
\text { All maturities }\end{array}$ & $\begin{array}{c}(2) \\
\text { Short-term }\end{array}$ & $\begin{array}{c}(3) \\
\text { Medium-term }\end{array}$ & $\begin{array}{c}(4) \\
\text { Long-term }\end{array}$ \\
\hline $\operatorname{Bank}_{\text {levy }} \operatorname{ligh}(0,1)$ & $\begin{array}{c}0.148 \\
(0.133)\end{array}$ & $\begin{array}{c}0.159 \\
(0.176)\end{array}$ & $\begin{array}{c}0.262 \\
(0.186)\end{array}$ & $\begin{array}{c}0.025 \\
(0.163)\end{array}$ \\
\hline Log total assets & $\begin{array}{c}-4.481 * * * \\
(1.065)\end{array}$ & $\begin{array}{c}-4.938 * * * \\
(1.692)\end{array}$ & $\begin{array}{l}-0.832 \\
(1.588)\end{array}$ & $\begin{array}{l}-0.850 \\
(1.686)\end{array}$ \\
\hline Log total assets ${ }^{2}$ & $\begin{array}{c}0.245 * * * \\
(0.049)\end{array}$ & $\begin{array}{c}0.270 * * * \\
(0.076)\end{array}$ & $\begin{array}{c}0.022 \\
(0.082)\end{array}$ & $\begin{array}{c}0.045 \\
(0.087)\end{array}$ \\
\hline Tier1 capital ratio & $\begin{array}{c}1.565 \\
(2.350)\end{array}$ & $\begin{array}{l}-2.372 \\
(4.444)\end{array}$ & $\begin{array}{c}3.169 \\
(2.358)\end{array}$ & $\begin{array}{l}2.490 * \\
(1.485)\end{array}$ \\
\hline NPL ratio & $\begin{array}{l}-0.120 \\
(1.896)\end{array}$ & $\begin{array}{l}-0.366 \\
(2.882)\end{array}$ & $\begin{array}{l}-0.945 \\
(1.749)\end{array}$ & $\begin{array}{c}0.375 \\
(1.667)\end{array}$ \\
\hline Cost-to-income ratio & $\begin{array}{c}0.010 \\
(0.976)\end{array}$ & $\begin{array}{c}0.008 \\
(1.078)\end{array}$ & $\begin{array}{c}0.320 \\
(0.790)\end{array}$ & $\begin{array}{l}-0.717 \\
(1.248)\end{array}$ \\
\hline RoA & $\begin{array}{l}-10.969 \\
(13.934)\end{array}$ & $\begin{array}{l}-26.405^{*} \\
(14.824)\end{array}$ & $\begin{array}{c}1.589 \\
(12.310)\end{array}$ & $\begin{array}{l}-12.580 \\
(14.136)\end{array}$ \\
\hline Liquidity ratio & $\begin{array}{c}1.491 \\
(1.175)\end{array}$ & $\begin{array}{c}1.947 \\
(1.940)\end{array}$ & $\begin{array}{c}0.836 \\
(1.686)\end{array}$ & $\begin{array}{c}1.680 \\
(2.227)\end{array}$ \\
\hline Merger dummy & $\begin{array}{l}-0.052 \\
(0.103)\end{array}$ & $\begin{array}{c}0.003 \\
(0.138)\end{array}$ & $\begin{array}{l}-0.017 \\
(0.118)\end{array}$ & $\begin{array}{l}-0.005 \\
(0.098)\end{array}$ \\
\hline Constant & $\begin{array}{c}23.193 * * * \\
(5.841) \\
\end{array}$ & $\begin{array}{c}24.925 * * * \\
(9.389)\end{array}$ & $\begin{array}{c}9.803 \\
(7.844)\end{array}$ & $\begin{array}{r}9.065 \\
(8.720)\end{array}$ \\
\hline Observations & 1,050 & 1,027 & 1,015 & 1,009 \\
\hline $\mathrm{R}^{2}$ & 0.638 & 0.610 & 0.314 & 0.420 \\
\hline Number of banks & 144 & 138 & 142 & 144 \\
\hline
\end{tabular}




\section{Table 15: Regression Results: Size Effect of Bank Levy on Deposit Rates}

This table shows the regression results of the estimation specified in Equation (3). The estimations are based on the sample of banks that report to the MFI interest rate statistics and cover 2003-2011. The sample is restricted to MFI banks that had more than $€ 300$ million of contribution-relevant liabilities. The dependent variable is the interest rate paid for newly received deposits for different maturities: overnight, short-term: $<1$ year; mediumterm: $\geq 1$ year. The effect of the bank levy ("Bank levy ${ }_{\text {high }}(0 / 1)$ ") is the coefficient on the dummy "Charged Bank high * After2010," which is equal to 1 in 2011 if the bank had contribution-relevant liabilities higher than $€ 10$ billion and 0 if its contribution-relevant liabilities were greater than $€ 300$ million but less than or equal to $€ 10$ billion. Total assets are expressed in million $€$. The independent variables comprise the CAMEL variables, as defined in Section 3.3, included with a lag. The merger dummy is equal to 1 if a merger took place in a given year and 0 otherwise. Time and bank fixed effects are included but not reported. The standard errors are robust to heteroscedasticity. $* * *, * * *$ indicate significance at the $10 \%, 5 \%, 1 \%$ levels, respectively.

\begin{tabular}{|c|c|c|c|c|}
\hline & $\begin{array}{c}\text { (1) } \\
\text { All maturities }\end{array}$ & $\begin{array}{c}(2) \\
\text { Overnight }\end{array}$ & $\begin{array}{c}(3) \\
\text { Short-term }\end{array}$ & $\begin{array}{c}(4) \\
\text { Medium-term }\end{array}$ \\
\hline Bank levy $_{h i g h}(0,1)$ & $\begin{array}{l}-0.112 \\
(0.103)\end{array}$ & $\begin{array}{c}-0.390 * * * \\
(0.109)\end{array}$ & $\begin{array}{c}-0.190 * * \\
(0.092)\end{array}$ & $\begin{array}{c}-0.417 * * \\
(0.180)\end{array}$ \\
\hline Log total assets & $\begin{array}{l}0.696^{*} \\
(0.416)\end{array}$ & $\begin{array}{c}0.110 \\
(0.440)\end{array}$ & $\begin{array}{c}0.889 * * \\
(0.379)\end{array}$ & $\begin{array}{l}-0.220 \\
(0.713)\end{array}$ \\
\hline Log total assets ${ }^{2}$ & $\begin{array}{c}-0.042 * * \\
(0.018)\end{array}$ & $\begin{array}{l}-0.013 \\
(0.023)\end{array}$ & $\begin{array}{c}-0.044 * * \\
(0.017)\end{array}$ & $\begin{array}{c}0.021 \\
(0.036)\end{array}$ \\
\hline Tier 1 capital ratio & $\begin{array}{l}2.495 * \\
(1.382)\end{array}$ & $\begin{array}{c}3.039 * * * \\
(1.108)\end{array}$ & $\begin{array}{c}1.652 \\
(1.149)\end{array}$ & $\begin{array}{c}1.954 \\
(1.680)\end{array}$ \\
\hline NPL ratio & $\begin{array}{l}-1.157 \\
(0.782)\end{array}$ & $\begin{array}{c}2.101 \\
(2.436)\end{array}$ & $\begin{array}{l}-1.087 \\
(0.664)\end{array}$ & $\begin{array}{l}-0.560 \\
(1.136)\end{array}$ \\
\hline Cost-to-income ratio & $\begin{array}{c}0.391 \\
(0.374)\end{array}$ & $\begin{array}{c}0.458 \\
(0.476)\end{array}$ & $\begin{array}{c}0.459 \\
(0.281)\end{array}$ & $\begin{array}{c}0.006 \\
(0.421)\end{array}$ \\
\hline RoA & $\begin{array}{c}7.261 \\
(4.624)\end{array}$ & $\begin{array}{c}5.397 \\
(6.890)\end{array}$ & $\begin{array}{l}-1.198 \\
(4.802)\end{array}$ & $\begin{array}{c}2.471 \\
(8.466)\end{array}$ \\
\hline Liquidity ratio & $\begin{array}{l}-1.368 * \\
(0.783)\end{array}$ & $\begin{array}{l}-1.293 \\
(0.805)\end{array}$ & $\begin{array}{l}-0.801 \\
(0.795)\end{array}$ & $\begin{array}{l}-1.234 \\
(1.048)\end{array}$ \\
\hline Merger dummy & $\begin{array}{c}0.017 \\
(0.065)\end{array}$ & $\begin{array}{l}-0.074 * \\
(0.038)\end{array}$ & $\begin{array}{c}0.034 \\
(0.061)\end{array}$ & $\begin{array}{l}-0.029 \\
(0.053)\end{array}$ \\
\hline Constant & $\begin{array}{l}-2.030 \\
(2.425) \\
\end{array}$ & $\begin{array}{l}-0.038 \\
(2.230)\end{array}$ & $\begin{array}{l}-3.979 * \\
(2.120)\end{array}$ & $\begin{array}{r}2.015 \\
(3.667) \\
\end{array}$ \\
\hline Observations & 1,024 & 1,038 & 999 & 944 \\
\hline $\mathrm{R}^{2}$ & 0.883 & 0.648 & 0.932 & 0.750 \\
\hline Number of banks & 141 & 139 & 132 & 139 \\
\hline
\end{tabular}




\section{Figure 1: Tax Payments and Contribution-Relevant Liabilities}

This graph plots the partial tax payments (in million $€$ ) resulting from the multiplication of contribution-relevant liabilities (in billion $€$ ) in different tax brackets with the respective tax rate. The tax rate for contribution-relevant liabilities $(L)$ smaller than or equal to $€ 300$ million is 0 . If a bank has contribution-relevant liabilities of more than $€ 300$ million, the amount exceeding this threshold is subject to the following progressive tax rate: 0.0002 ( $€ 300$ million $<L \leq € 10$ billion), 0.0003 ( $€ 10$ billion $<L \leq € 100$ billion), 0.0004 ( $€ 100$ billion $<L \leq € 200$ billion), 0.0005 ( $€ 200$ billion $<L \leq € 300$ billion), and 0.0006 ( $L>€ 300$ billion).

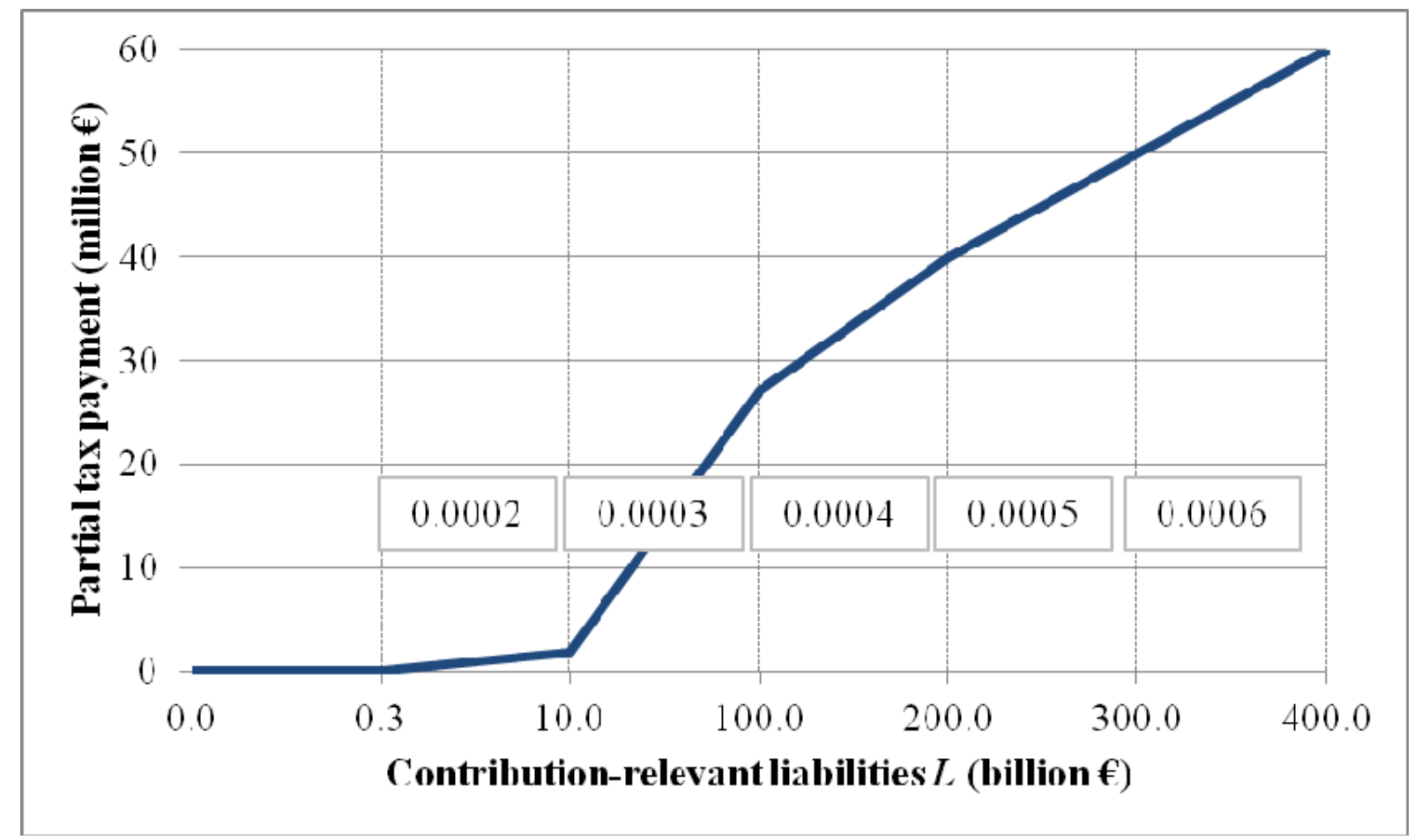


Figure 2: Contribution-Relevant Liabilities, 2011 versus 2012

This graph plots contribution-relevant liabilities for the year 2011 against those of 2012. The graphs are based on balance sheet data from 2010 or 2011. On the left, data from all banks included in the sample are aggregated to obtain contribution-relevant liabilities by bank group (in billion $€$ ). On the right, contribution-relevant liabilities by bank group are scaled by total assets of the respective bank group. Source: Deutsche Bundesbank, own calculations.
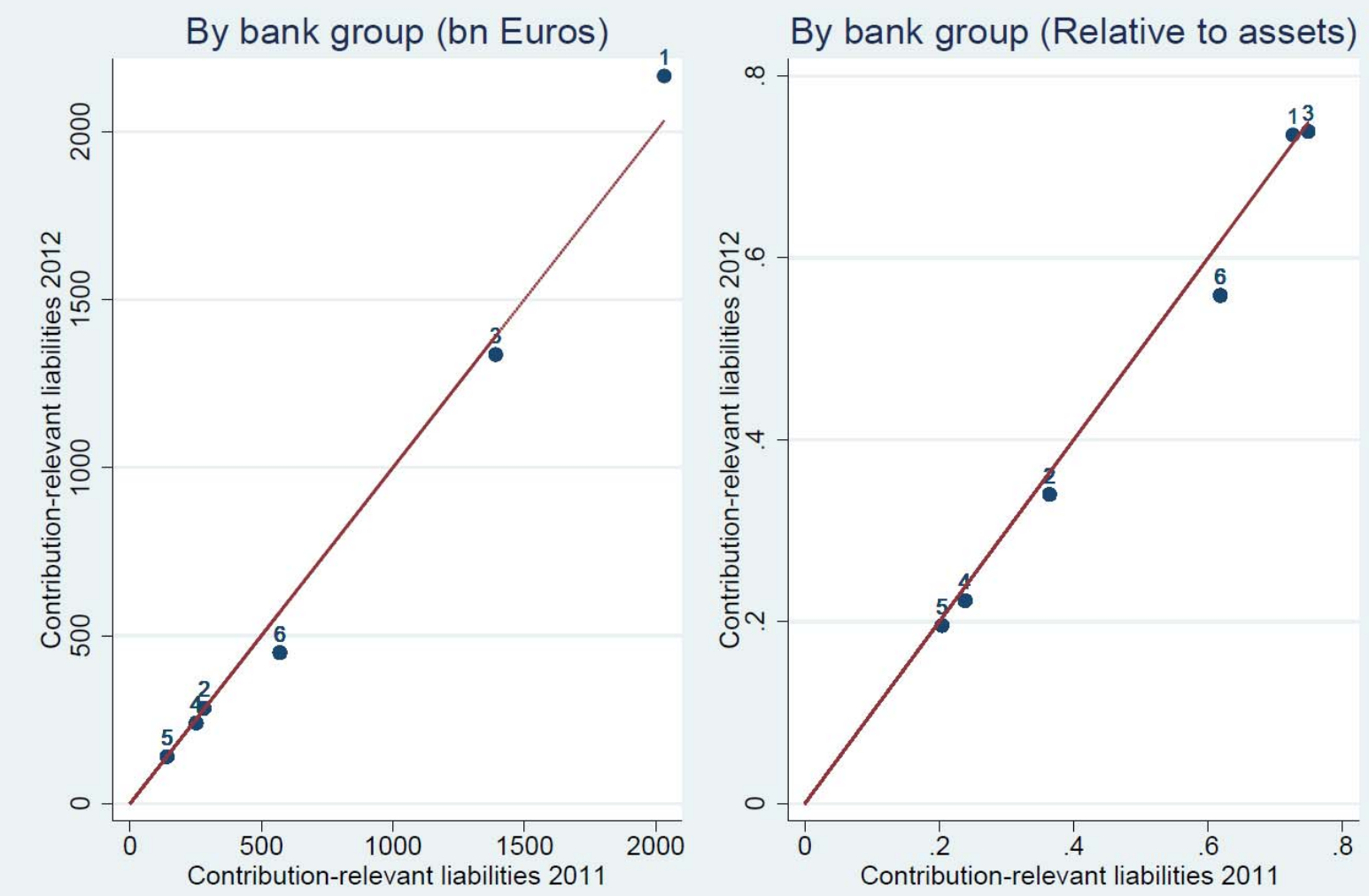

1: Large commercial banks 2: Other commercial banks 3: Head institutes (savings banks \& credit unions) 4: Savings banks 5 : Credit unions 6: Mortgage banks 


\section{Figure 3: Histogram Contribution-Relevant Liabilities}

This graph shows the distribution of contribution-relevant liabilities (in billion $€$ ) in the second interval, $€ 300$ million $<L \leq € 10$ billion, for 2011 and 2012, using balance sheet data from 2010 and 2011. According to the Kolmogorov-Smirnov test, we cannot reject the equality of the distribution functions for contribution-relevant liabilities in 2011 and 2012. Source: Deutsche Bundesbank, own calculations.
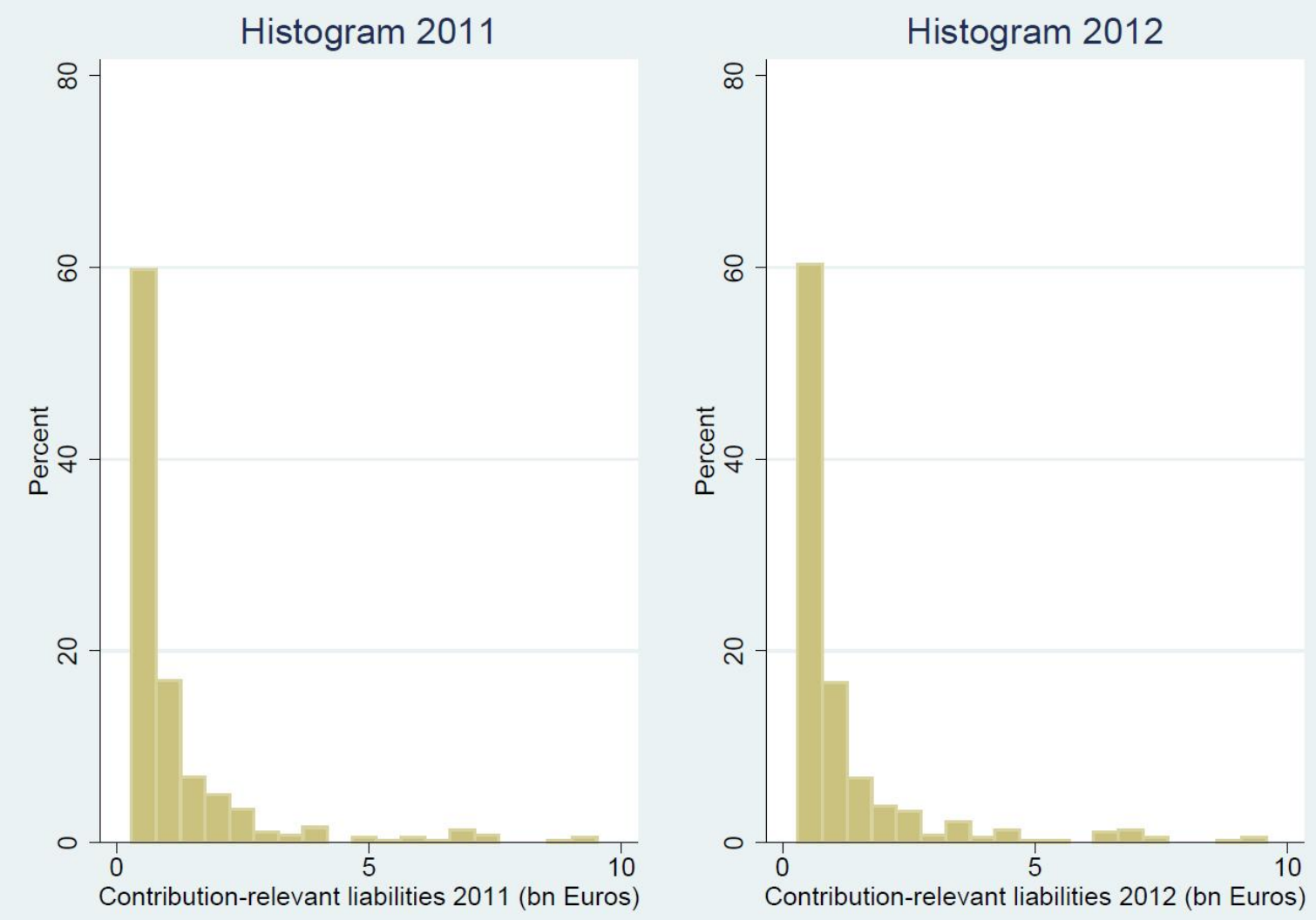


\section{Figure 4: Derivatives of BIS Banks}

This figure shows the development of derivative exposures (in billion \$) of German banks reporting to the Bank for International Settlements (BIS). Both over-the-counter (OTC) and exchange-traded (ET) derivative positions are depicted. Source: Semiannual OTC derivatives statistics and statistics on exchange traded derivatives, Bank for International Settlements.

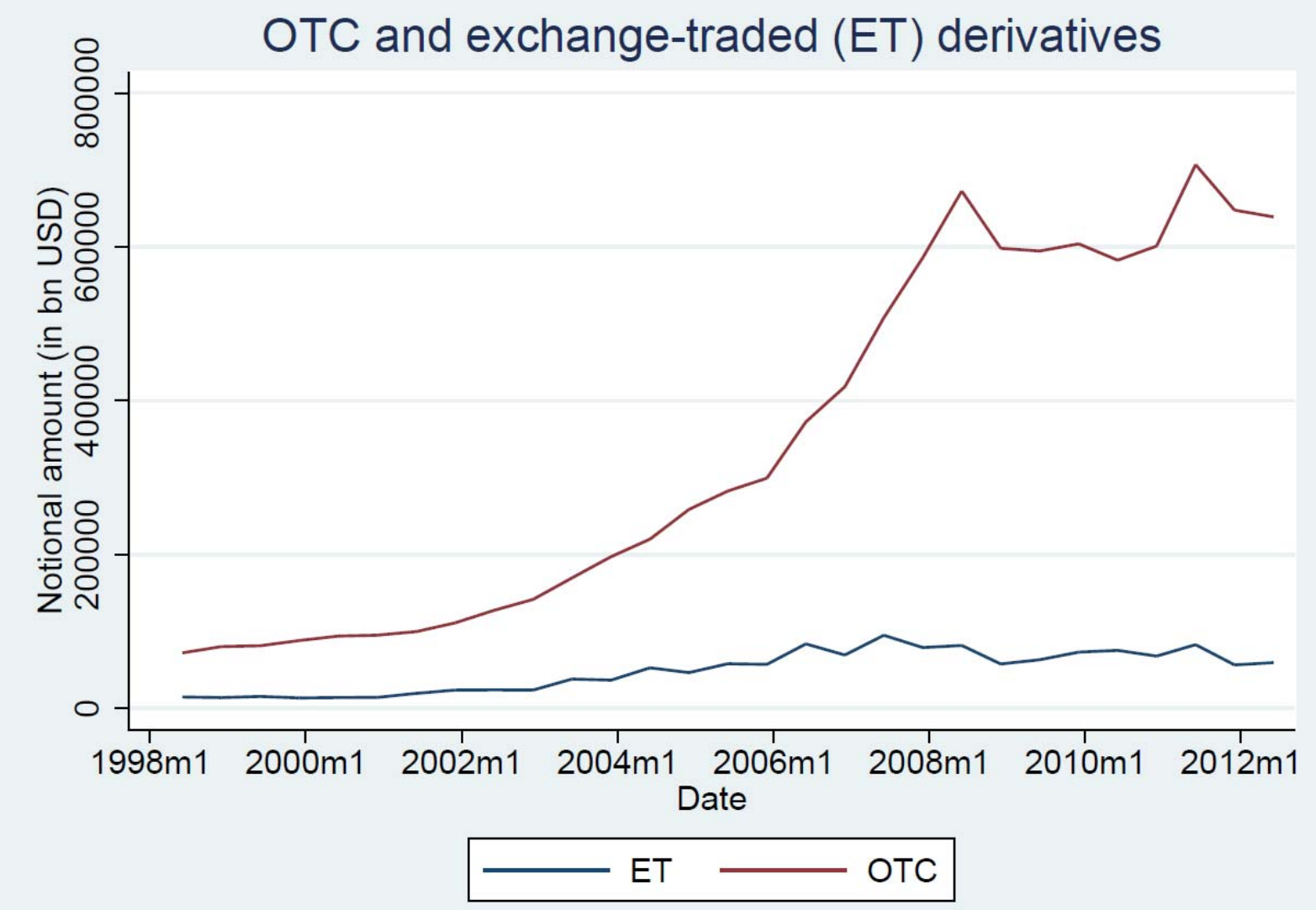




\section{Figure 5: Time Trends in Loan Volumes, Loan and Deposit Rates}

This figure compares the average pattern of (a) newly issued loans and total lending, (b) loan rates, and (c) deposit rates for the sample of banks reporting to the MFI interest rate statistics over 2003-2011. Control group refers to banks with contribution-relevant liabilities smaller than or equal to $€ 300$ million. Treatment group contains banks that must pay taxes on their contribution-relevant liability positions. Panel a shows the average pattern for the log of newly issued loans (in thousand $€$ ) and the log of the total loan volume (in thousand $€$ ) for the control and the treatment group. Panel $b$ refers to average interest rates $(\%)$ on new loans with different maturities again for the control and the treatment group. Panel c corresponds to average interest rates (\%) on new deposits with different maturities. Source: MFI interest rate statistics and balance sheet reports, Deutsche Bundesbank.

(a) Loan volumes

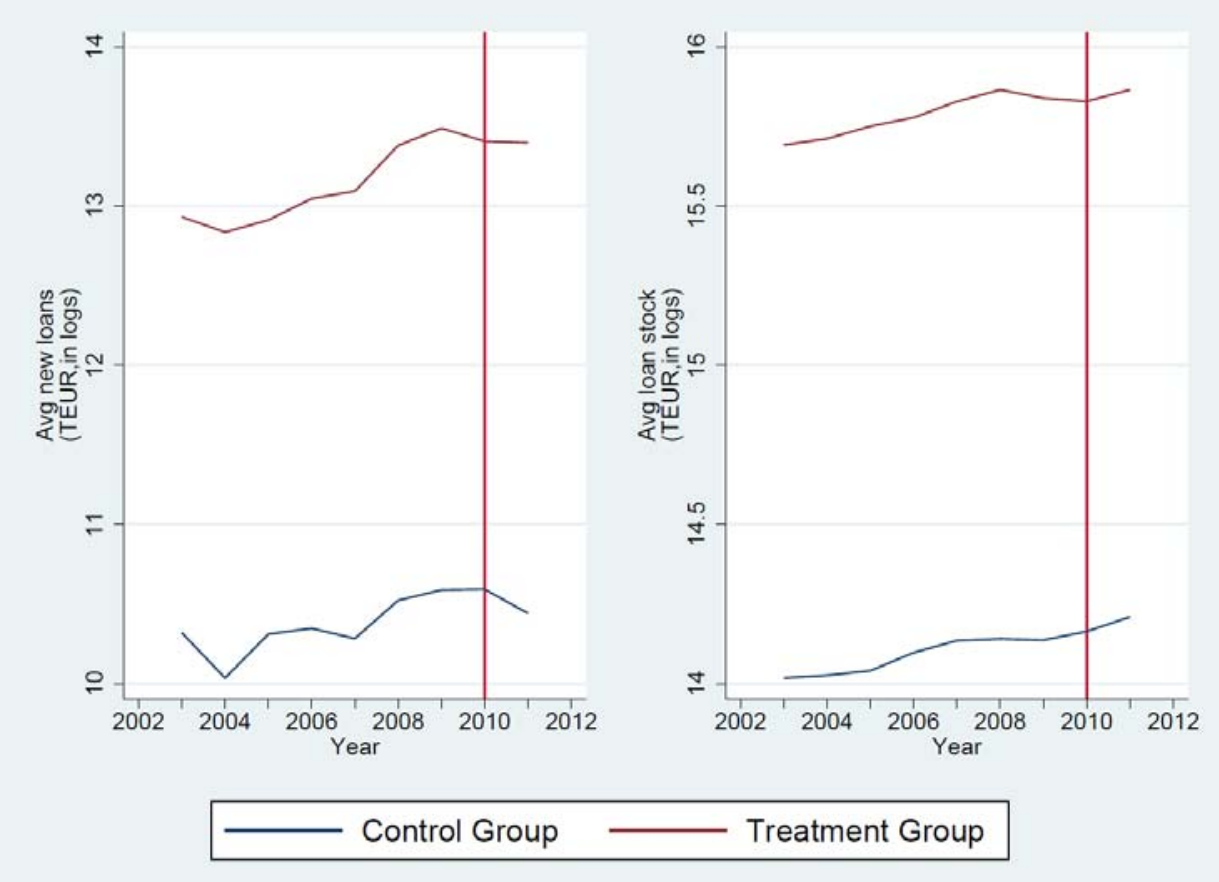

(b) Loan rates
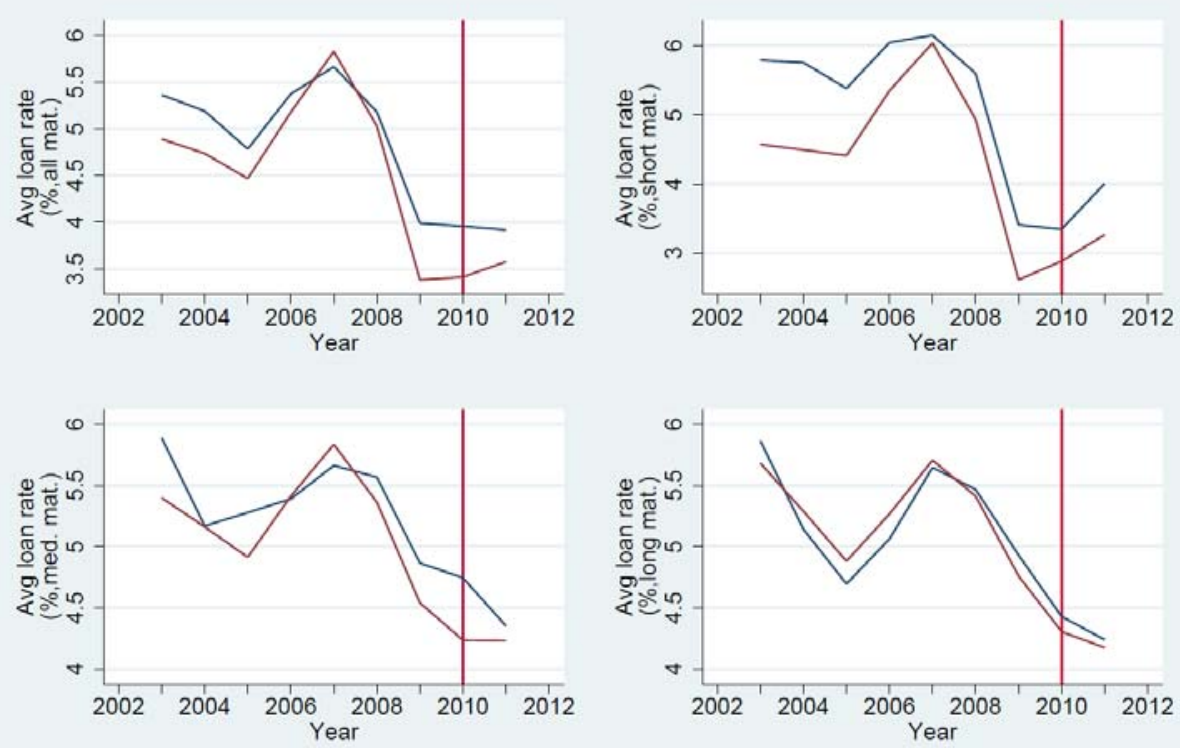

Control Group

Treatment Group 
(c) Deposit rates
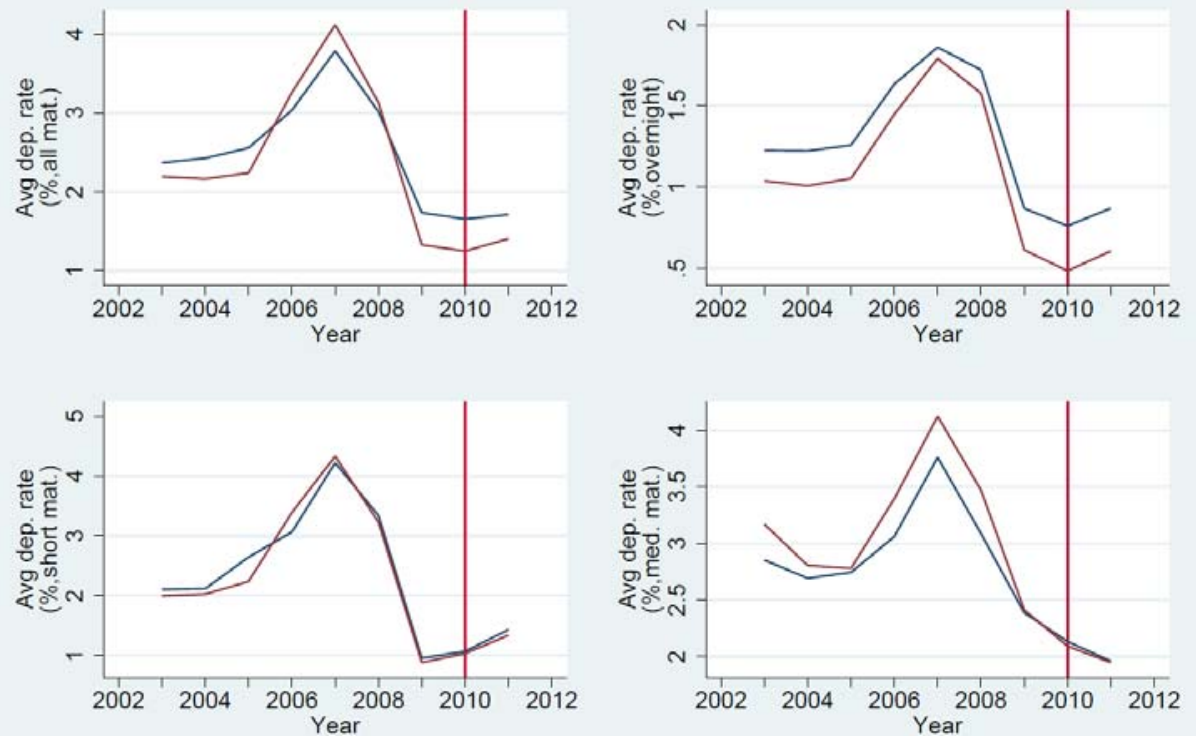

Control Group

Treatment Group 